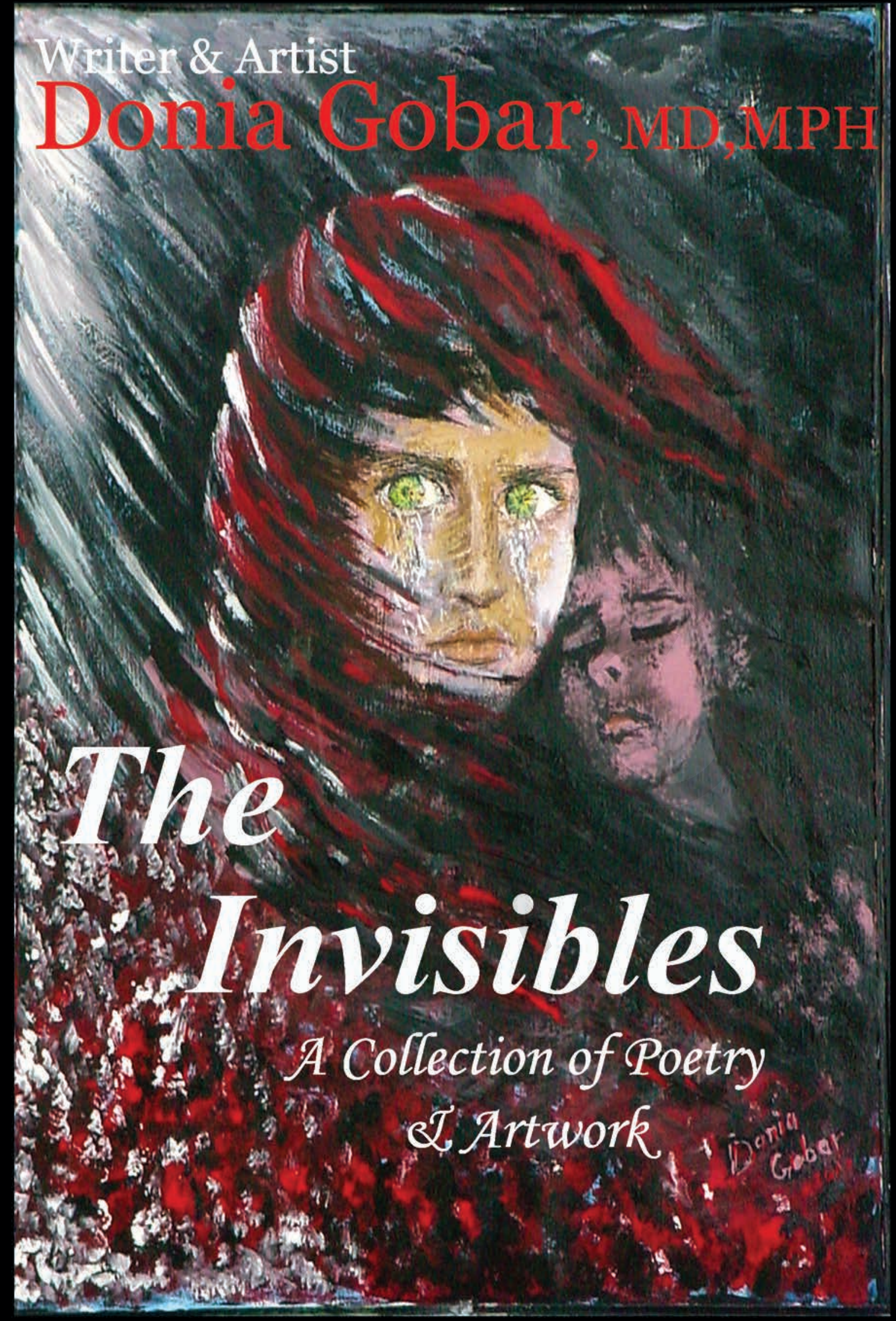

\title{
The Invisibles
}

A Collection of

Poetry \& Artwork

\author{
Writer \& Artist: Donia Gobar, MD, MPH
}

Donia Gobar has been writing over the years, originally in Persian or Dari, and later in English. However, this is her first attempt to publish her work in a series of individual collections.

The Invisibles is her first collection of poetry. It includes some of her paintings. Donia Gobar describes this work as "an abstract mosaic of written and visual art-each different, yet all connected through the core issues perceived and reflected by the author-all gathered around life, which in its patient warmth and beauty, in its cold unforgiving shadows, in its unpredictable blazes or blizzards, and in its boring uneventful circles-always and always is able to turn pens and brushes into storytellerscareless of their hoarse voices and bleeding cells, or the gentle lull of their senses...still the stories will be remembered and will be told, around the campfire of life." 


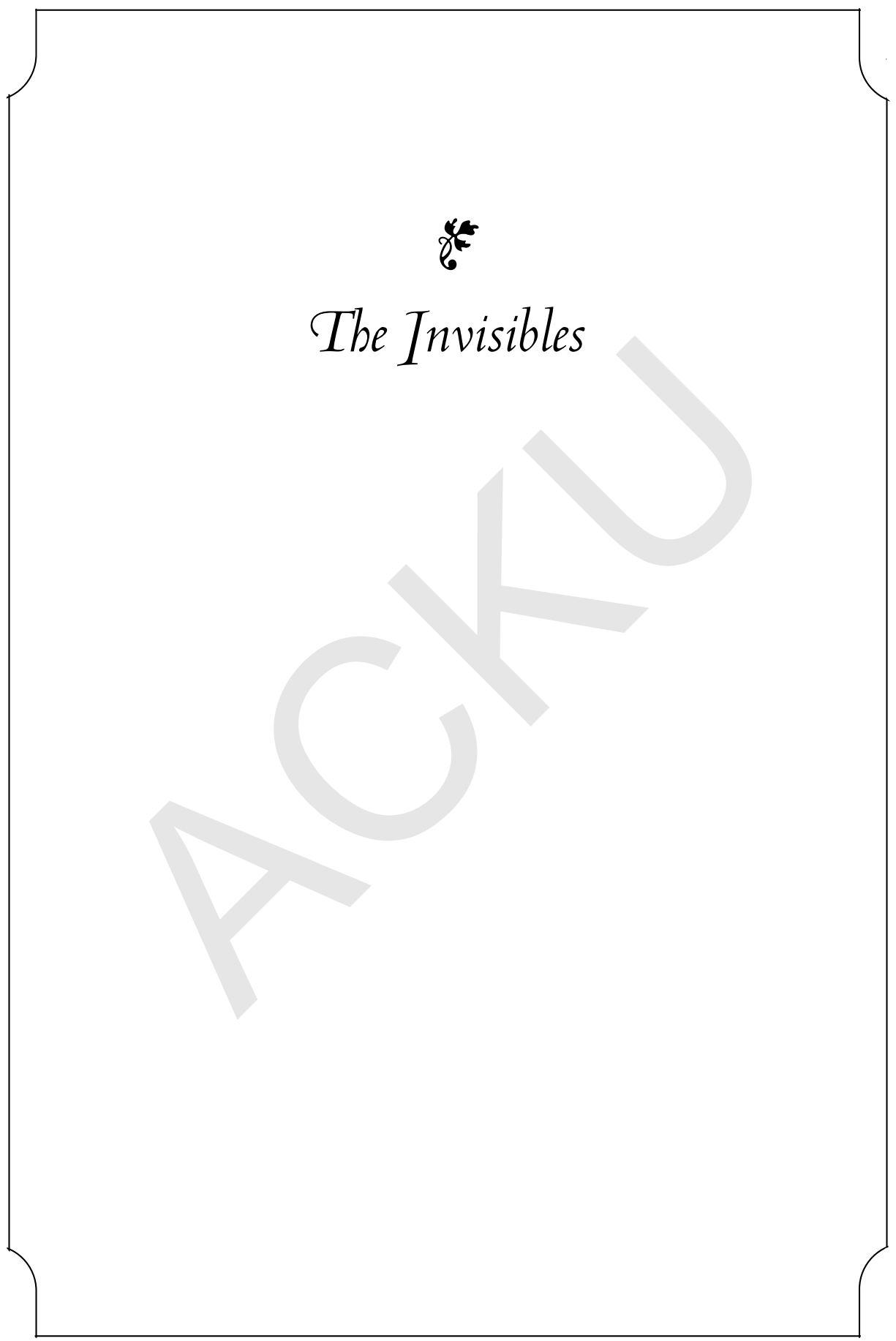




$$
\text { pe }
$$




\section{The Invisibles}

A Collection of Poetry \& Artwork

\section{Writer \& Artist: Donia Gobar, MD,} $\mathrm{MPH}$

iUniverse, Inc.

New York Lincoln Shanghai 


\title{
The Invisibles A Collection of Poetry \& Artwork
}

\author{
All Rights Reserved (C) 2003 by Donia Gobar, MD, MPH
}

No part of this book may be reproduced or transmitted in any form or by any means, graphic, electronic, or mechanical, including photocopying, recording, taping, or by any information storage retrieval system, without the written permission of the publisher.

\author{
iUniverse, Inc. \\ For information address: \\ iUniverse, Inc. \\ 2021 Pine Lake Road, Suite 100 \\ Lincoln, NE 68512 \\ www.iuniverse.com
}

Front cover design, layout, and painting by Donia Gobar (author)

Back cover: design and layout by Donia Gobar (author)

(author's photos, book description, short biography)

ISBN: 0-595-29303-4 (pbk)

ISBN: 0-595-75026-5 (cloth)

Printed in the United States of America 
Dedicated

To

The Innocent People of the World 


$$
\text { pe }
$$




\section{Contents List of Poems}

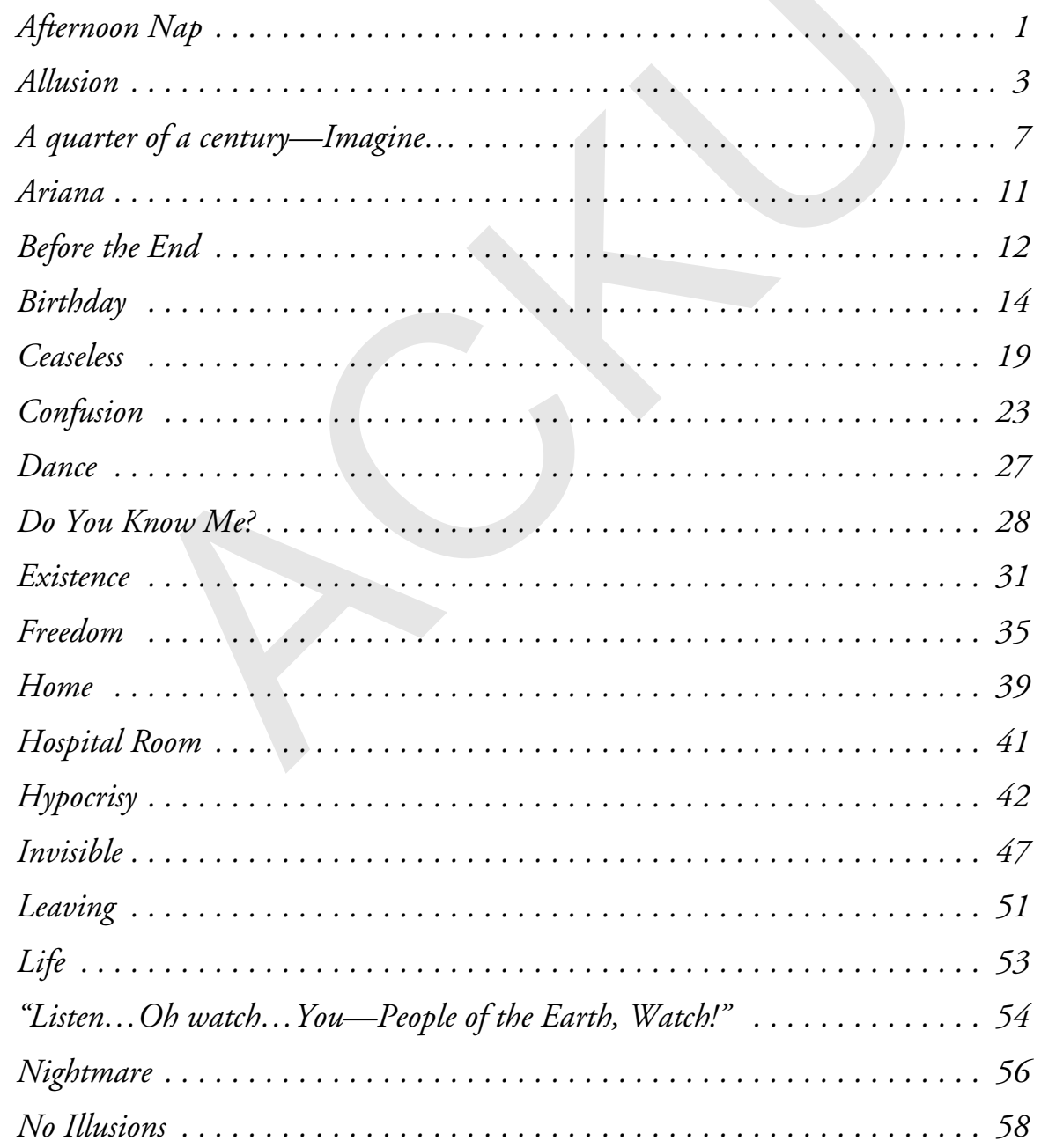


The Invisibles

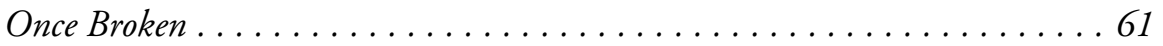

Overboard ..............................63

Remember? ...........................67

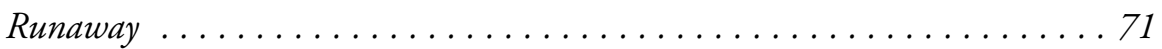

Stars Are Raining . . . . . . . . . . . . . . . . . . . 75

Swings ................................ 77

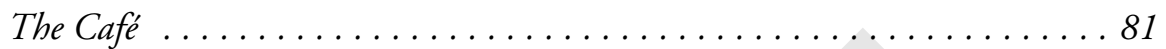

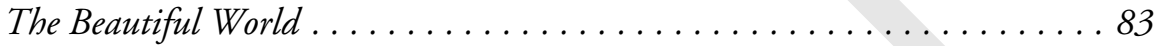

The Closing Doors ............................. 85

The Last Season . . . . . . . . . . . . . . . . . . . . . . . 87

The Mute Shore In Me . . . . . . . . . . . . . . . . . . 89

The Portrait In Ink . . . . . . . . . . . . . . . . . . . . . . . . . . . . 90

The Teacher .................................. 91

The Ugly Face of Power . . . . . . . . . . . . . . . . . . . . 93

They Can't Take Freedom From Me ..................... 95

Untouched .............................. 97

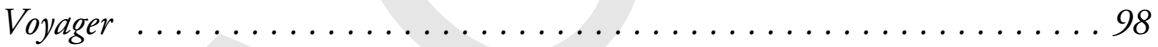

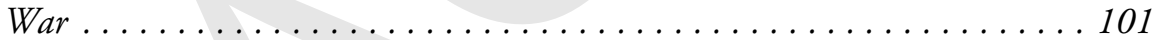

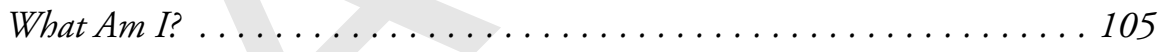

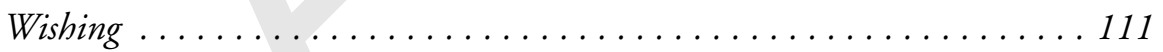

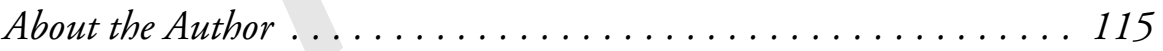




\section{Contents _List of Paintings}

(originals are all in color and of larger sizes)

Front cover (36"X28" acrylic*)—Listen...Oh Watch...

Note*: In creation of this painting, the artist (author) was inspired by the picture of "Afghan Girl" photographed by Steve McCurry.

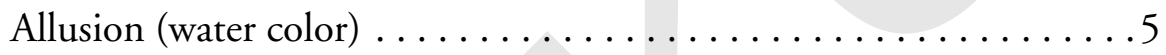

A Quarter of...Imagine (water color) $\ldots \ldots \ldots \ldots \ldots \ldots . . . . . .9$

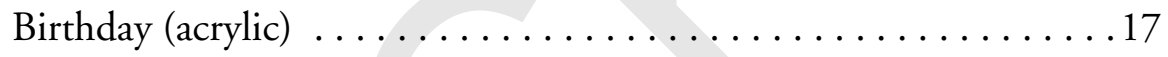

Ceaseless (acrylic) ...............................

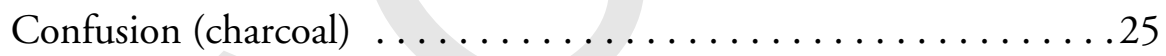

Do you know me? (water color) . . . . . . . . . . . . . . . . . 29

Existence (acrylic) ............................ 33

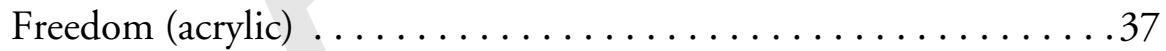

Hypocrisy (acrylic) ............................... 45

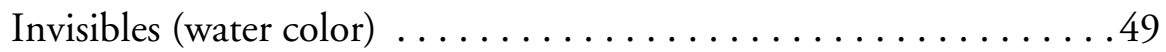

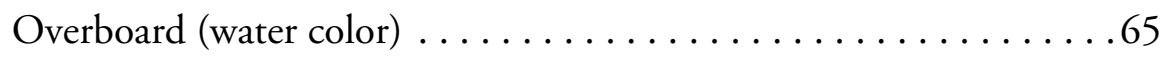

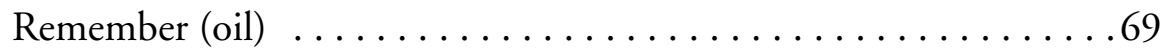

Runaway (acrylic) .............................. 73

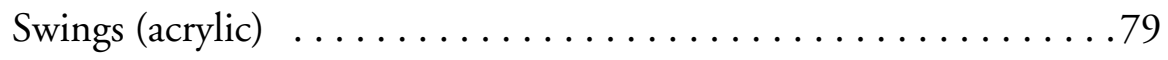

Voyager (water color) ............................. 99 
War (acrylic) ........................... 103

What Am I? (water color) . . . . . . . . . . . . . . . . . . 109

Wishing (water color) $\ldots \ldots \ldots \ldots \ldots \ldots \ldots \ldots \ldots \ldots$ 


\title{
Acknowledgement
}

\author{
My deepest gratitude to my parents,
} whose wisdom and life examples have been, and always will be, my guiding light.

I am grateful to my daughter Carrie (Afsana), my "kindred spirit," whose personality and outlook contribute to humanity and bring joy to my life.

My sincere appreciation for the guidance, love, and friendship of my family and those whom I love dearly, whose existences enrich and beautify the world.

I am thankful to Nate Mayer, a young and gifted individual, for his technical assistance and skillful photography in preparation of the artwork included in this book.

My sincere thanks to Rifka Keilson and Valerie Haas, the iUniverse, Inc., Publishing Service representatives, for their support and guidance during the manuscript submission process.

I am impressed by the professionalism of the expert editors at iUniverse, and am truly grateful for their recognition and review of my work.

Finally, I thank iUniverse, Inc. for giving me the chance to dedicate my writing and artwork to the innocent people of the world.

Donia Gobar

dgobard@yahoo.com 


$$
\text { pe }
$$


Humanity survives through wisdom, courage, and justice. Violence is never the answer to problems of the world. And, truth-the unconditional truth, is the key to humanity.

- Donia Gobar 


$$
\text { pe }
$$


Regardless of who, where, and when, we all are responsible for the path that humanity takes, and for what the bistory of bumanity will hold for its future generations.

-Donia Gobar 


$$
\text { pe }
$$




\section{Afternoon Nap}

On a green, shimmering summer day

the little boy tiptoed out with a silent pray;

that his mother in deep sleep may stay,

and he, from his needed nap, could get away.

The smell of grass and roses all around.

The weeping willows shadowed the ground,

as their soft emerald hair touched the ground.

The boy became a whisper in summer sound.

The heated earth burned his naked feet,

running, barely touching the baking street.

Gasping, he reached the shaded retreat,

beside the joyful, singing, sheltered creek.

The cool bank embraced his tiny chest.

On the old oak a little bird chirped in a nest.

The tadpole gang rushed on their quest.

On the boy's face, a big smile came to rest.

A second stretched to a million years.

In his never-ending world, no tears, no fears.

His fingers made clay castles and piers.

The future became younger by a thousand years.

The gleaming summer day was fading.

The cheeky, playful squirrels were racing. 
Sunset found the boy, softly breathing; eyes shut, smiling in his hideout, dreaming.

The breeze gently ruffled his light hair.

The hero on his horse was riding unaware.

Dream rode beside him, sweet and fair;

"No afternoon nap," whispered she in his ear.

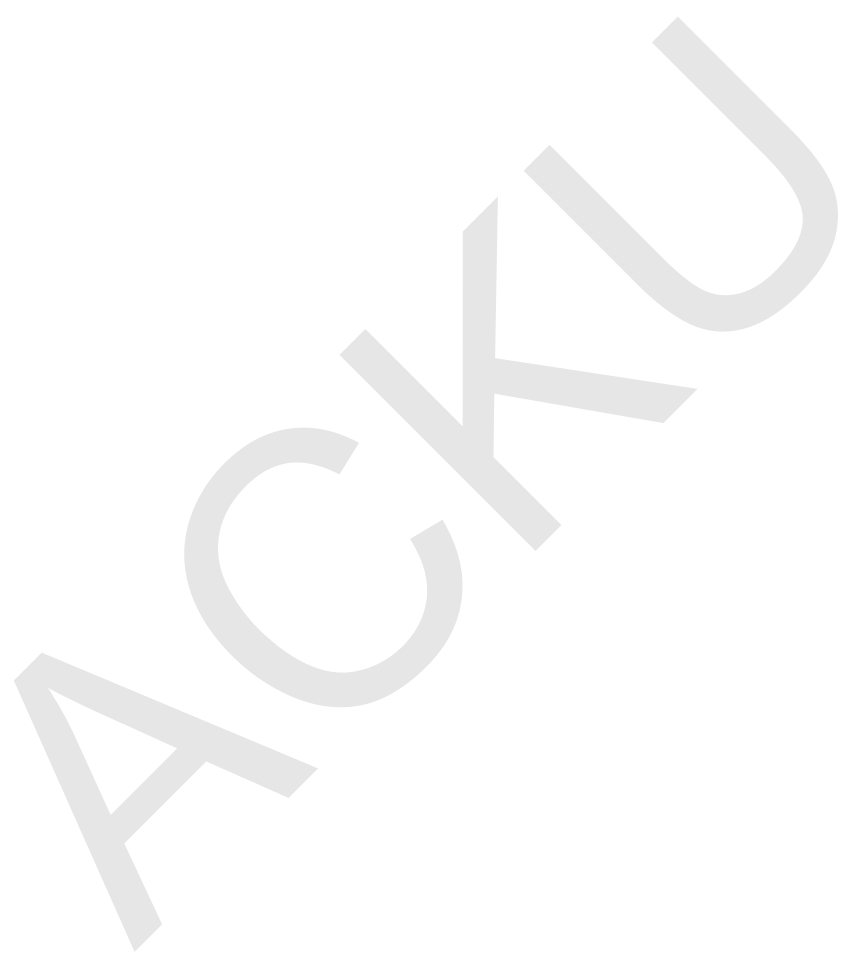




\section{Allusion}

In white shimmering nights, in dark days, in moonlit skies, in beaming sunrays, she was a soft raindrop, a candle's light, a star's kiss, an angle's sight.

O night...

Her heart was the marble in life's hand; or was it a fledgling in hunter's band? Her mind-a clean page in thought's hand, or was it a soft bed in storm's land? O night, tell me!

Her gaze was speaker of children's hopes; or was it a panorama of weeping souls? Her fingers-pilgrims on legend's road, or were they scribers of stories untold? Oh, night...O mysterious dark night.

Now...her eyes - the old pilgrims of lives, and her lips-a silent seal for victim's lives? The falling tears - confused in stormy waves... the world-weary pilgrim - tempered and brave... $\mathrm{O}$ proud vague night.

Starlight became sparks under iron heels. Angels' songs became shrill morbid yells.

The tranquil spring became storm, became storm...

In the lands of deserts and seas, became floods, became flames

O creepy, dark, cold night. 


$$
\text { pe }
$$


Donia Gobar, MD, MPH

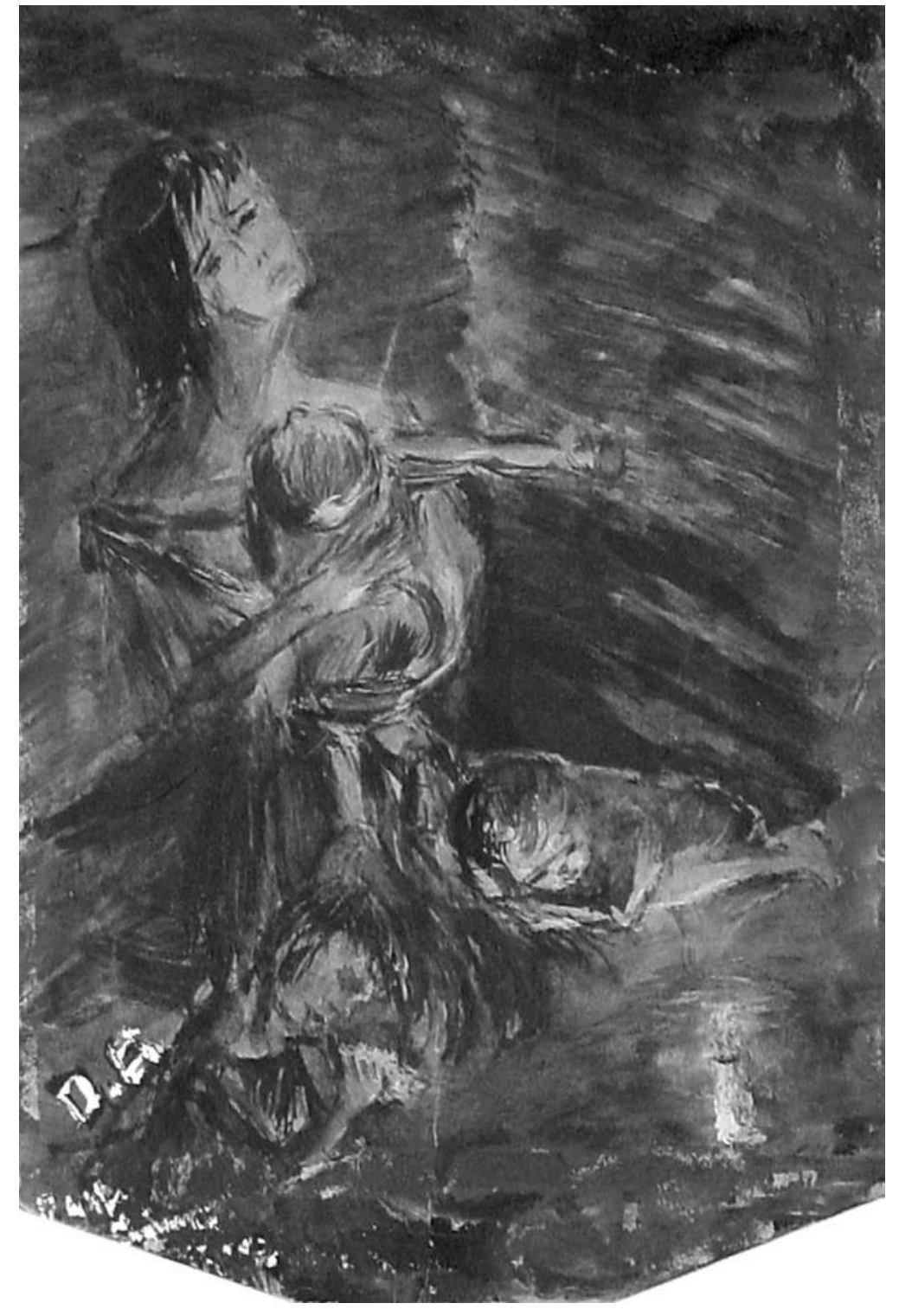

Allusions 


$$
\text { pe }
$$




\section{A quarter of a century- Imagine...}

Imagine you were a child

woken by the loud sounds,

and screams,

as the mother of bombs

has shaken the grounds

and broken homes and body parts

scattered around,

and you,

watching

the disfigured body of your mother

laying down, on a mud floor,

and the sudden lash of pain...

"Whose leg is there?-A yard away..."

Imagine you trudge along

through ruins of a lost city...

Your bloody half-leg

dangling behind

through bits and pieces of bodies

leaving a red trail behind.

Under a misty gray sky,

all alone-a six-year-old child.

and you cry quietly,

far away...

Imagine!

The military bases 
The winning hounds,

And the gloating generals,

The panicked losing troops,

And the plans for the next bombing

The bottles of vodka...

And the innocent, sacrificial solders-

whose names you may never know-

saluting, following orders...

Destroyed towns and cultures...

And the dried-up wells...

And you ask yourself,

Why?

What for? 
Donia Gobar, MD, MPH

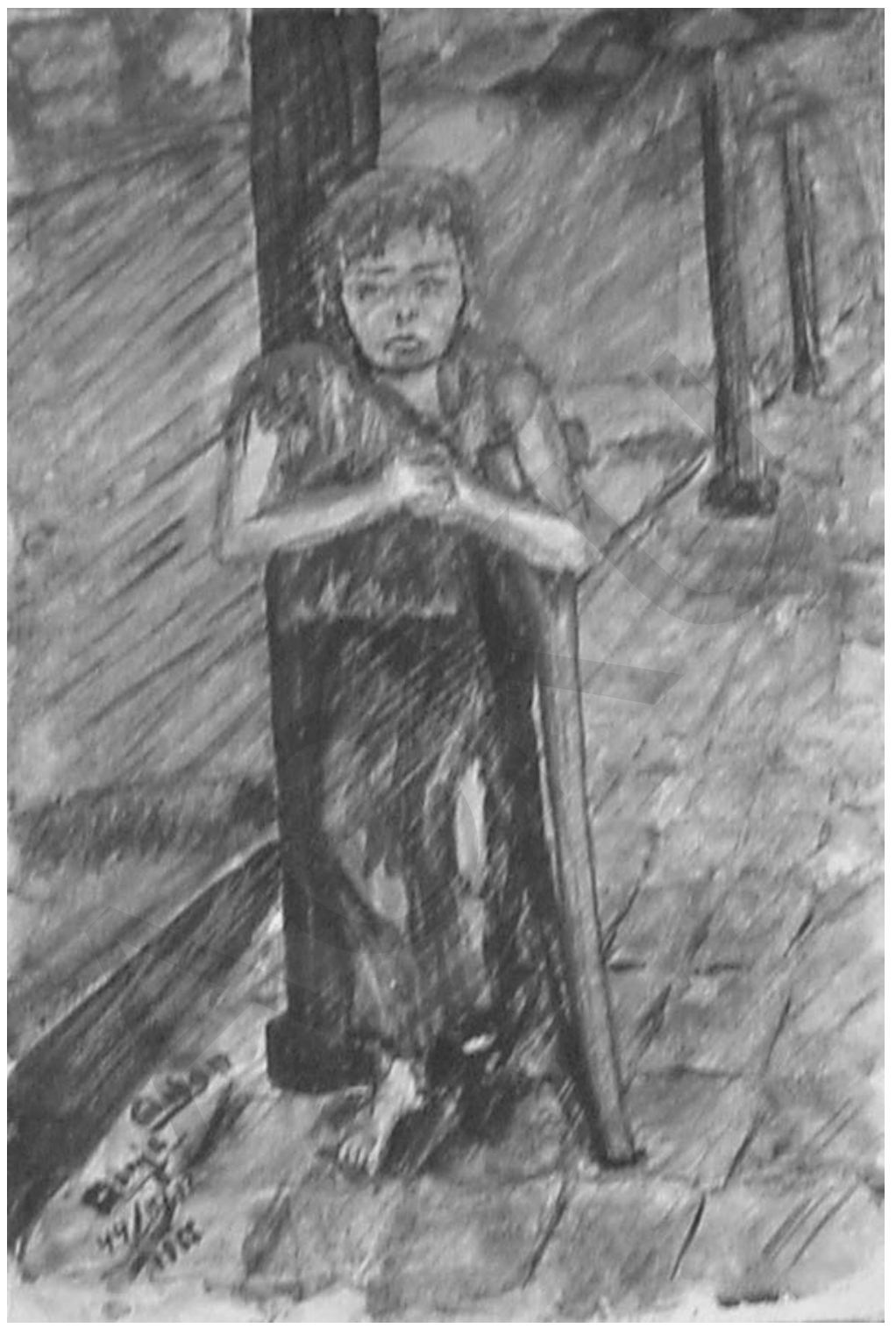

Imagine 


$$
\text { pe }
$$




\section{Ariana ${ }^{1}$ \\ (Dedicated to my country of birth)}

Such a sad silence...

This bottomless whirlpool of grief

O...the gasping airless senses

and the old dry tears

still burning,

still running

on dusty ruins of Beloved Ariana

Did I hear Her bitter laughter?

Did I hear Her whisper?

"I Will Never Be Gone...

I will never be gone...

I will never be gone..."

1. Ariana ("Aryana") is the ancient name of Afghanistan

$$
\sim 11 \sim
$$




\section{Before the End}

Nightlife Bar's green lights hiss

and slobber

over the cobalt stone sidewalks

in search of passing drunkards

and lonesome souls.

I walk in hallways lined with daunting norms

where I search for human faces

behind bleak masks.

My feet, tired and bruised

inside this misfit life,

bought and sold by those I don't even know...

Some strange strength elevates me

above my life;

and I gaze over the wreckage of my own,

while

crying for souls I don't even know...

Irony surfs on the waves of salty laughter,

crushing at the coasts I used to know.

The little girl running against the wind,

laughing,

steps into my age-colored shoes,

dancing.

Reality chuckles,

and she disappears in time...

Last night I found a picture of mine,

delicate figure,

dark shoulder-length waves,

a half-smile, 
with brave young life in embrace,

looking down,

in a side-cast shy gaze,

her hands raised with grace

in an Eastern dance...

Now, mirror finds me-watching, in serene silence, the evanescent moments of fall, and of mine.

A brave welcome, a half-smile...

A fresh breeze,

whispering aged wisdom's songs,

touches my heart-

now slightly trembling,

in the chill of time,

before winter,

before night... 
The Invisibles

\section{Birtbday}

On that cold Thursday afternoon

under a dome-shaped roof

I was born in an exile land.

My mother and my father,

looking at a dusty distance,

thinking of human blossoms

and life's untimely frost,

in that exile land.

Years have passed

but

the warmth of their love has last

through life's stormy casts...

in all exile lands.

Now...they are gone forever.

Many frosts have come

and gone,

before time,

and lingering too long.

Branches have trembled in cold nights

and lovely leaves

have turned into orphans, forlorn.

Fall is pouring its sweet sadness

before dusk,

over the shimmering surface

of a lonely pond.

My tired heart is running,

losing count of time. 
The child born under the dome-shaped roof is kneeling down on God's land, offering all her love,

all her life, to her mother, to her father, in this exile land. 


$$
\text { pe }
$$




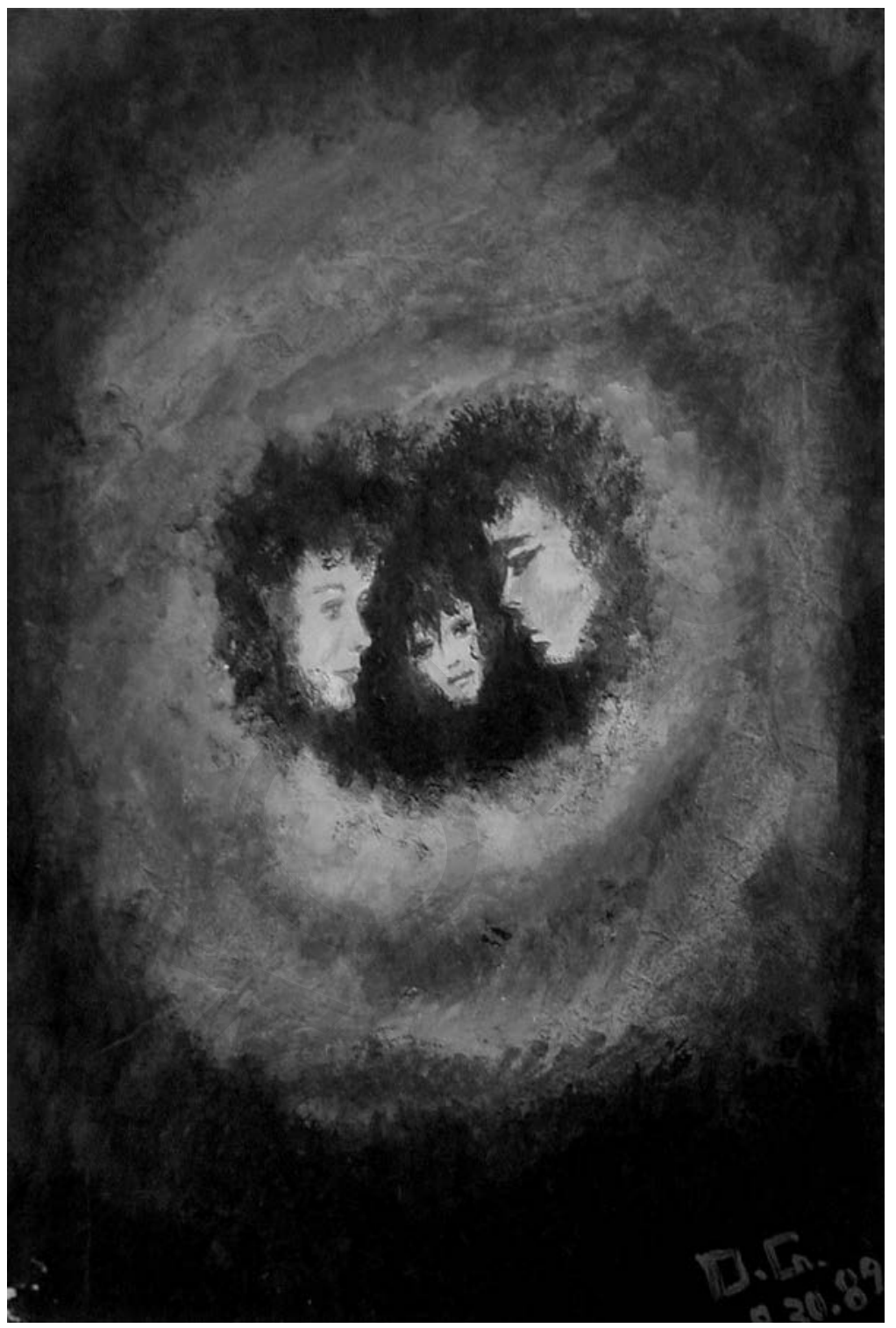

Birthday

$\sim 17 \sim$ 


$$
\text { pe }
$$




\section{Ceaselesd}

Across the room I saw you-among all.

Your eyes-

the shaded river in fall.

Your voice-

the words of a hero,

as rushing tides on a blue night shore,

echoed in the brave world of allure.

Time had stood still.

Distance had disappeared.

And voices had vanished - till

I could breath again,

think again...

"Who were you?"

When you held my hand

in safety of your grasping, strong hands;

my mind, hastily, had whispered,

"When will I see you—or, at all?"

I had wondered-

that night in fall.

Now, across the life borders,

my thoughts linger, rather sadly,

on the edge of distance between us-

the infinity...

And as the lonely silence weeps,

my mind whispers,

absentmindedly,

"Where is the honest grasp of your hands?" 
"Where does echo

your rushing laughter's sound...?”

And the memory tides sway me

on a blue life shore-

to smile,

and to cry,

as I remember,

the first time I ever knew you

and the last time I ever saw you. 
Donia Gobar, MD, MPH
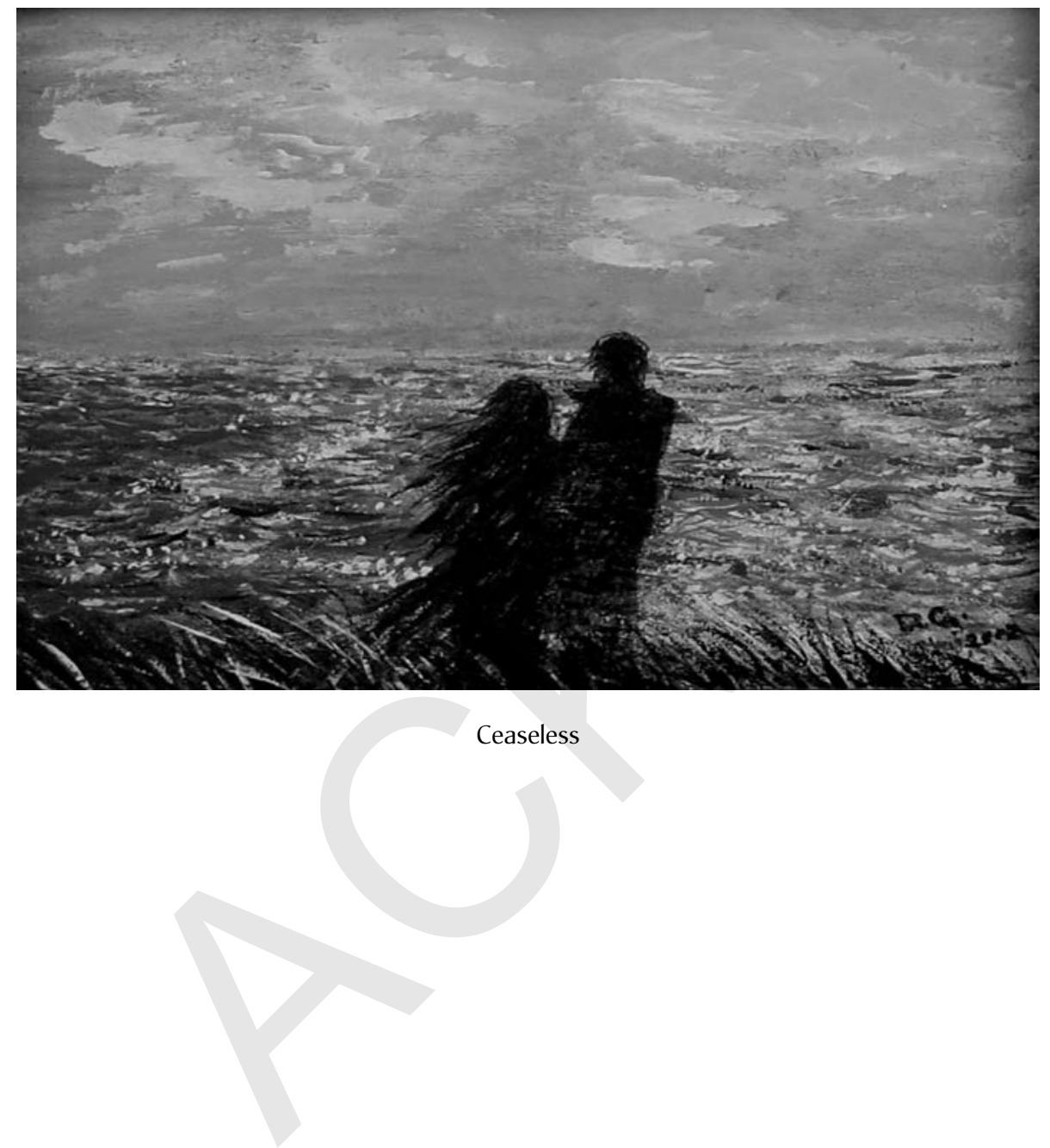


$$
\text { pe }
$$




\section{Confusion}

Eagles whispered to eagles,

"Look upon $M A N$, rushing along...

Meeting to meeting, day after day.”

Trees trembled, shedding leaves in sorrow,

"Forms and forms, covers-covering truth, office to office, and files to files."

Rats stayed silent in awe, while

Chairmen cleared their throats,

declared the solutions to problems,

motioned, and seconded the items in agendas.

Old janitors on night shifts,

their backs bent, walked slowly,

wiping the cigar dust off leather furniture

and carpeted floors...

Problems spread their skirts in darkness,

and "confusion"

grew in sparkles of blind lights...

Eagles circled in the sky above,

and the child looked up and wondered,

"What are the grownups doing?" 


$$
\text { pe }
$$


Donia Gobar, MD, MPH

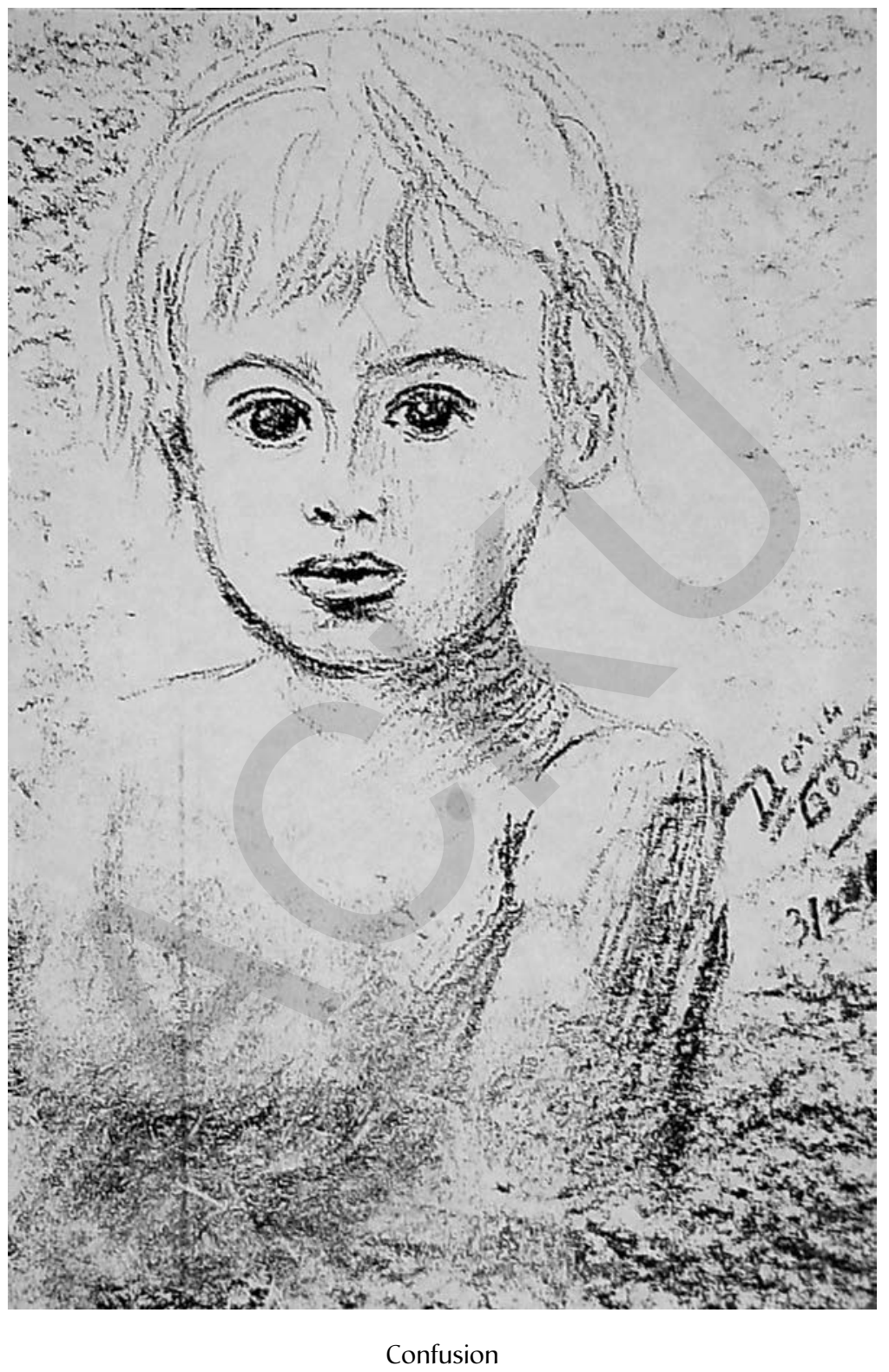




$$
\text { pe }
$$




\section{Dance}

My pounding heart

overflows

under the cascade of tears,

and

my dark eyes

drown

in foggy memories...

In Blue Danube's trance,

hazily,

sad melodies,

and warm bodies

sleep,

and old shadows

creep...

My weathered soul soars

over faraway oceans,

and

we dance with Strauss

in the arms of centuries...

On a hot summer night,

lazily,

the small towns

sleep... 


\section{Do You Know Me?}

I am in cold broken houses

On sizzling country roads

In dark alleys of glorious cities

In hospital corridors

On the steps of forgotten shacks

In the age of electronics...

I am there-where you live.

I am breathing — a helpless child, a fragment in an adult game, forgotten in an adult world...

Do you know me? 
Donia Gobar, MD, MPH

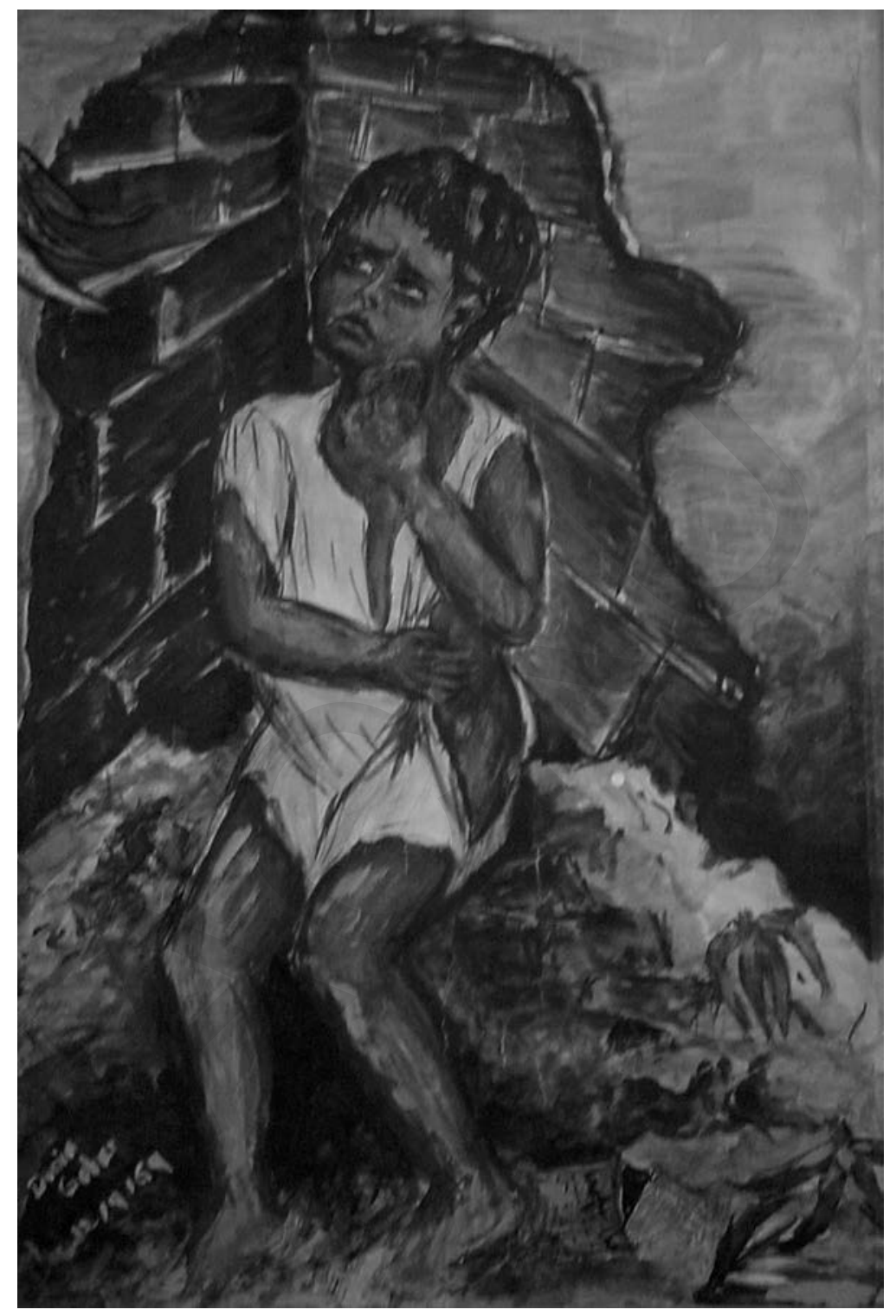

Do You Know Me? 


$$
\text { pe }
$$




\section{Existence}

A decade of "past" rushed

into a whirlpool of thousands of circles

with clearness of yesterday,

and I,

dizzy and lost,

backed away

to the present moment...

and the moment stretched in slow-motion

into decades and decades of past

inside the present's blurry passage. 


$$
\text { pe }
$$




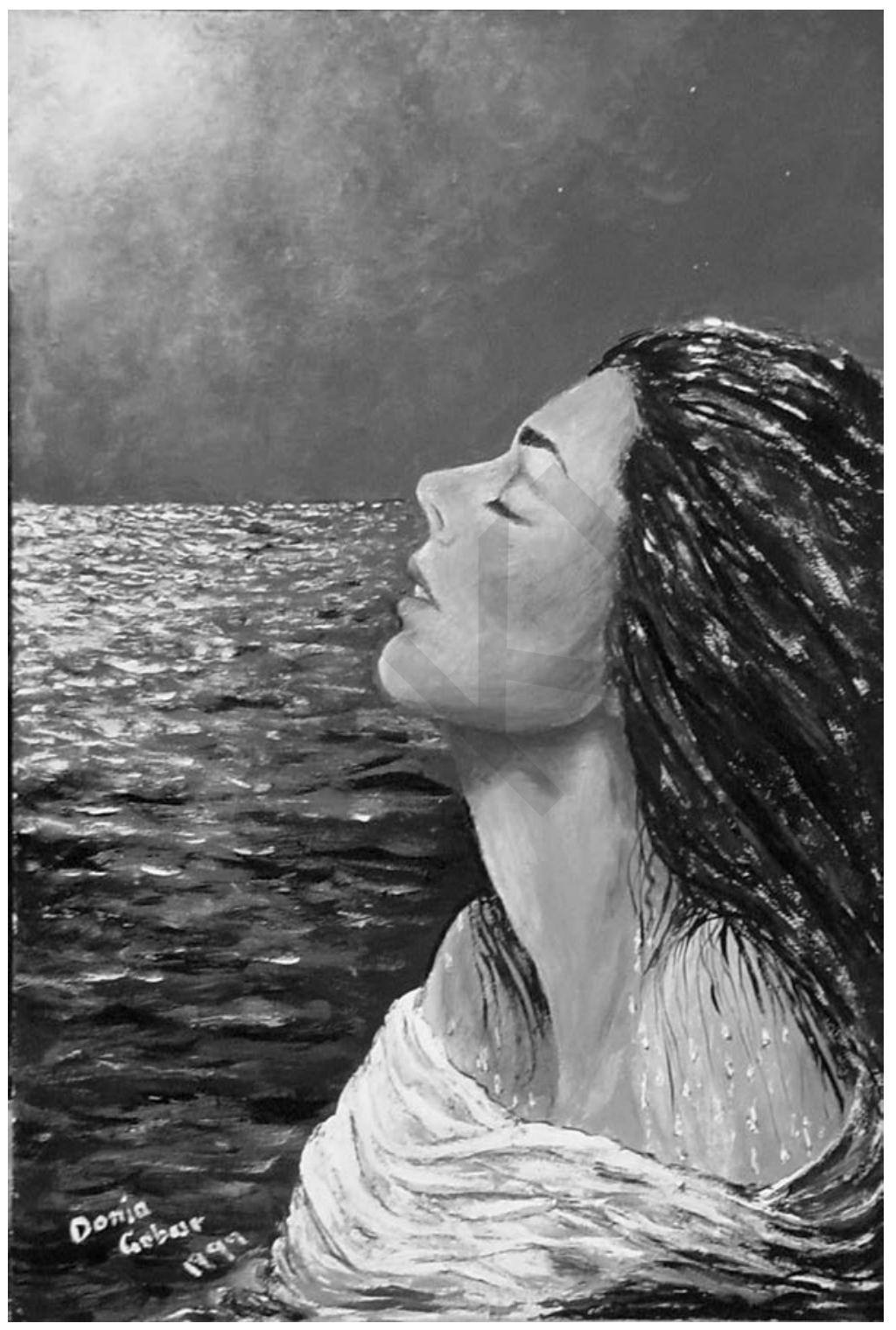

Existence 


$$
\text { pe }
$$




\section{Freedom}

In the face of ravishing sorrows,

through the race of gruesome nights,

and threatening tomorrows,

through the chains of despotic powers

and the deceitful facade of plotting towers,

bleeding,

stepping on the sharp knives of

devious,

sanctimonious,

fanatic powers

Freedom keeps walking...

Freedom keeps laughing... 


$$
\text { pe }
$$


Donia Gobar, MD, MPH

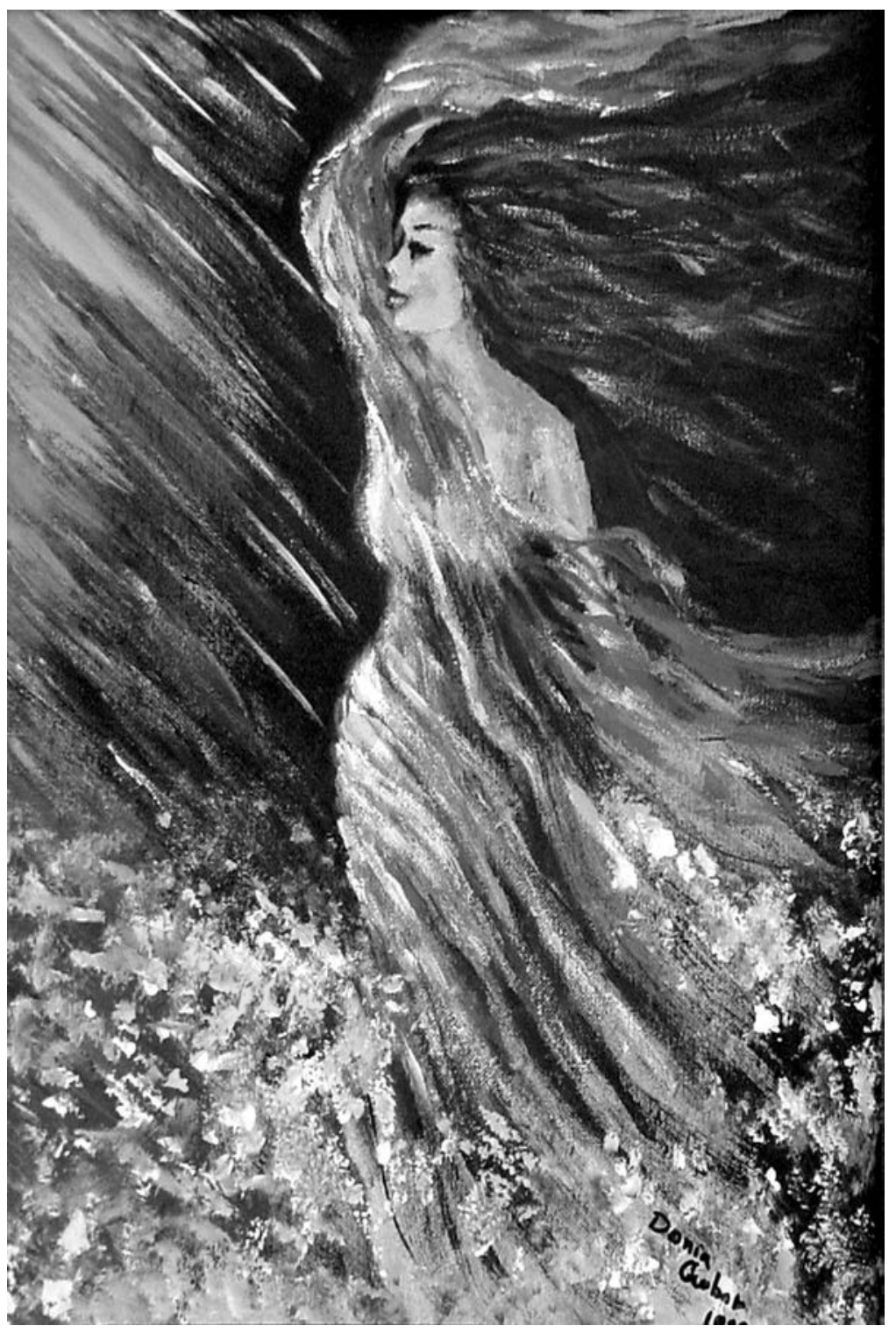

Freedom 


$$
\text { pe }
$$




\section{Home}

Would she ever see the land

where red tulips grew?

Would she ever see again

those emerald slopes?

Would she ever see Bamyan Lake-

the liquid shimmering turquoise blue?

Where Buddha sculptures used to stare...

Those peaceful dear old stone pair...

And will the children be running

on clover-covered grounds,

starry-eyed,

grubbing,

holding

the utopian skirts of tomorrow...

laughing, laughing...?

Would she ever?

Could she ever?

Hush, hush,

you grown-old, wandering alien.

Oh, regrets of yesterday,

where are her hopes?

And you-pains of life-mares,

where are her sweet dreams?

The blind war has crushed all the tulips, and inside the bloodstained ruins-

mourning, 
the wind echoes-

weeping, weeping...

Old songs, empty space,

my reflection, and I-

white hair, puffy eyes-

whispering, whispering...

"Would I ever? Could I ever?" 


\section{Hospital Room}

The icicles of waiting moments melt soundlessly

inside the slow, advancing tides of time.

Repositioning her aching head

on the warmed, white pillow,

she looks at the peach-colored walls,

and the "Little Sweet Moments" sign,

while the "touch and pass" half words

test

the patience of a semiconscious mind.

Looming question marks play

Hide and Seek games,

with her slowly waking-up thoughts

in the silence of room 223,

piercing

her mind and

the strong odor of antiseptics.

She gazes at the

yellow and purple common flowers,

as the stripes of white plastic shade

let the light of Pittsburg's gray sky

peak inside room 223

in vertical lines,

where she has lost

a day of her life. 
The Invisibles

\section{Hypocrisy}

"Do not fight!" they command,

watching the upturned young faces,

"Trust us!" they demand.

While the secret doors open and shut,

before where weapons are put to test,

"Our weapons must be the best!"

They make it their quest.

"Be fair!" they declare

as children play,

"Tell the truth!" with care

they say.

Yet,

they, as adults,

may hide the facts every day,

unashamed, unafraid,

as they play and play.

"Share what is yours!"

they give orders

to the young-and to the weak.

"Not yours!" they claim

as they take

that of others,

fencing the new borders.

What for...?

O...what for?

They will regret

someday

at the gates of death- 
someday

leaving this world-

someday,

with no power, with no wealth...

And the curtains will fall—someday,

revealing the face of Hypocrisy-

someday...

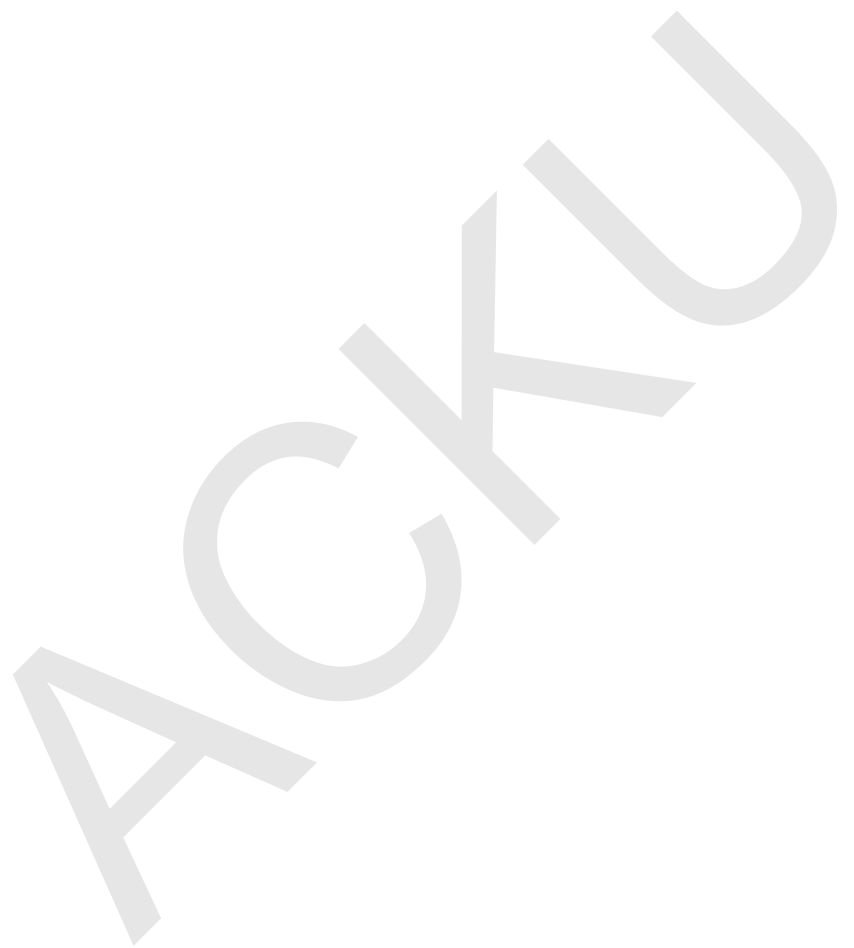




$$
\text { pe }
$$


Donia Gobar, MD, MPH

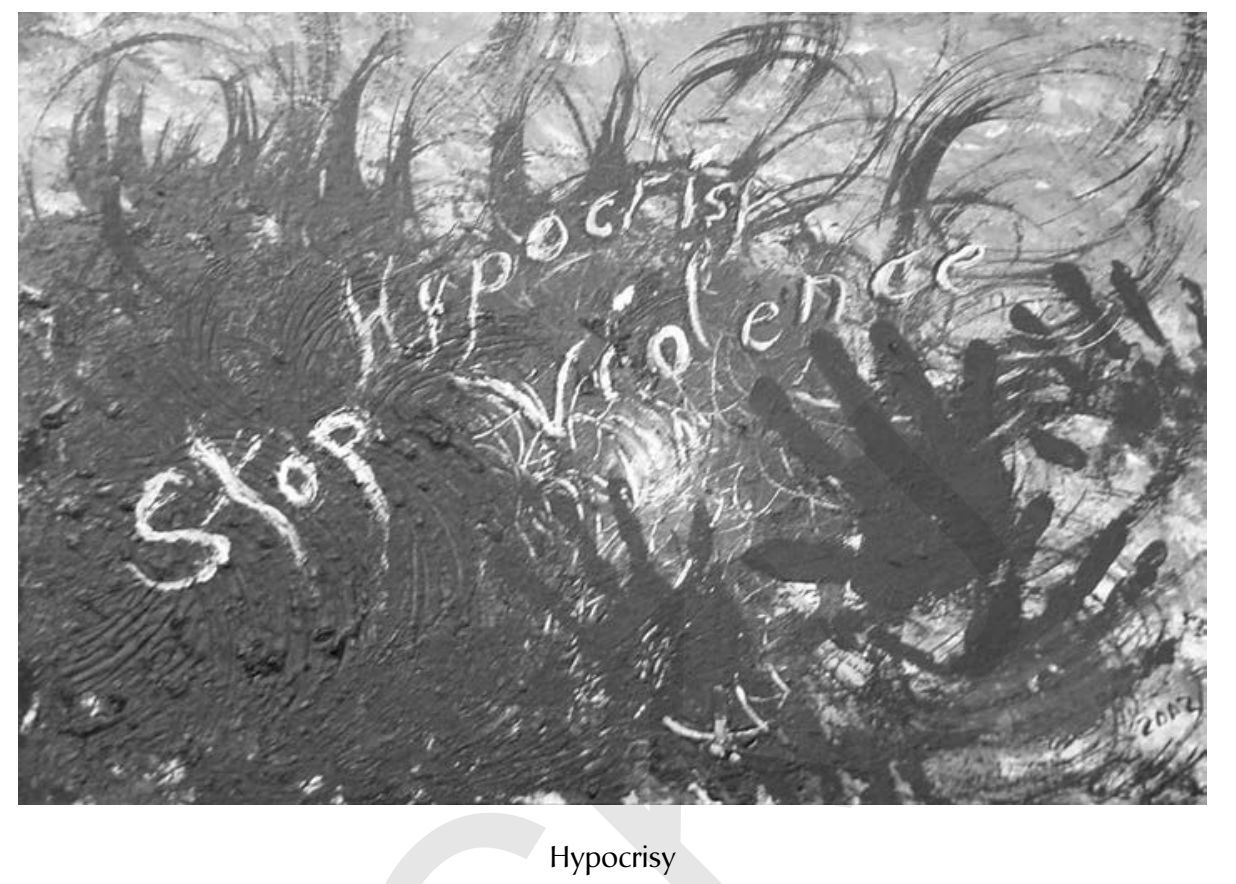

$\sim 45 \sim$ 


$$
\text { pe }
$$




\section{Invisible}

The pain is back-

in the pit of her heart,

where not a soul can see,

this horribly empty house-

wherein pain stretches

its dull weight,

settling in,

testing

the limits of human strength.

The slow-burning heat,

dragging behind it,

the flattering, wounded bird-

once her heart,

once the okay feeling,

up,

up to her throat,

up to her eyes,

up to the back of her neck,

to the back of her shoulders,

where it lingers;

where it stands guard;

not to let

the fleeting moments of hope

enter her aching soul.

Only...now and then

a sob breaks

the silence of her bare, gray world,

and her forehead presses down

on her thin fingers, 
like storm-bearing clouds on fragile limbs of an uprooted tree.

The palm of her hand

finds her swollen eyelids.

Tears—hot and sad

run down,

and she does not know what to do.

The candle, still lemon yellow, stays in the gray light of dusk

The long leaves of the forgotten plant, thirsty,

droop down the old window.

The hungry, red-eyed baby-

no more crying,

now and then...moaning,

is still

tapping on his mother's thin shoulders...

The red-eyed mother, playing tough,

her chin-up,

her arms holding-

the hungry, cold treasure...

Both in dark-

the invisibles... 
Donia Gobar, MD, $M P H$

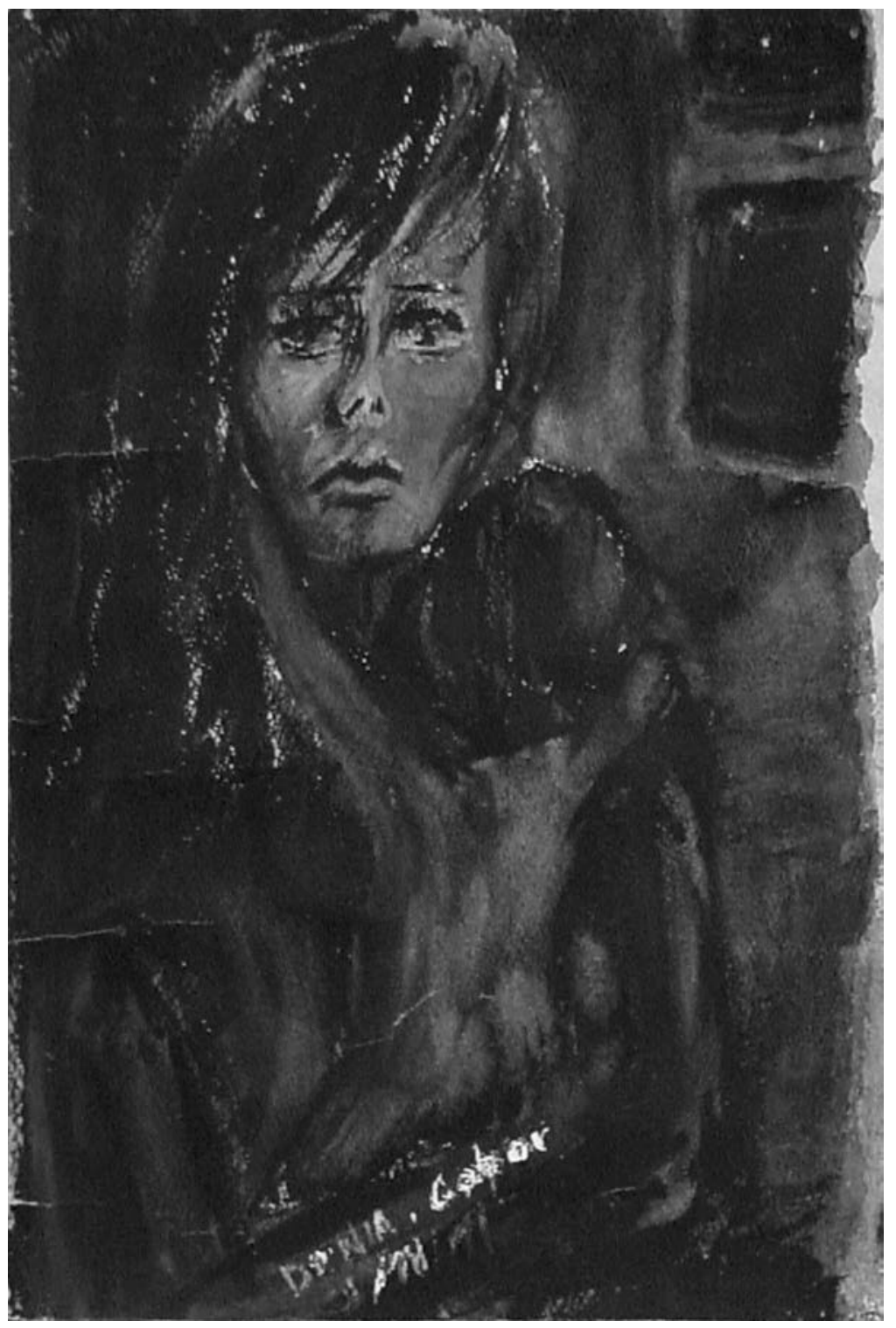

Invisible 


$$
\text { pe }
$$




\section{Leaving}

I look at her small, pale face.

Her black-pearl eyes,

lost in sadness-

on the verge of words and tears...

She is not crying.

Standing there, three feet tall, in a blue checkered sundress,

her arms thin and tan,

her small feet, lost in her shoes-

no socks...

She is just looking.

I press her hand three times,

meaning, I love you,

and she two times,

meaning me too.

I look into her eyes,

as my tears burn their way...

Time forces the distance to stretch,

and I have to go,

"It is okay to cry, see? I do,"

I say,

her thin shoulders warm and still.

I know I have to go.

I say "goodbye" and "see you again..."

as I step away... backwards,

my hand waving,

as I pull my bags along,

through the security service gateway

disappearing, slowly,

she is just standing there, 
next to grown-ups,

waving, slowly

her tiny hands reaching up,

as high as they can...

I can't see her face anymore.

But I know she is not crying...

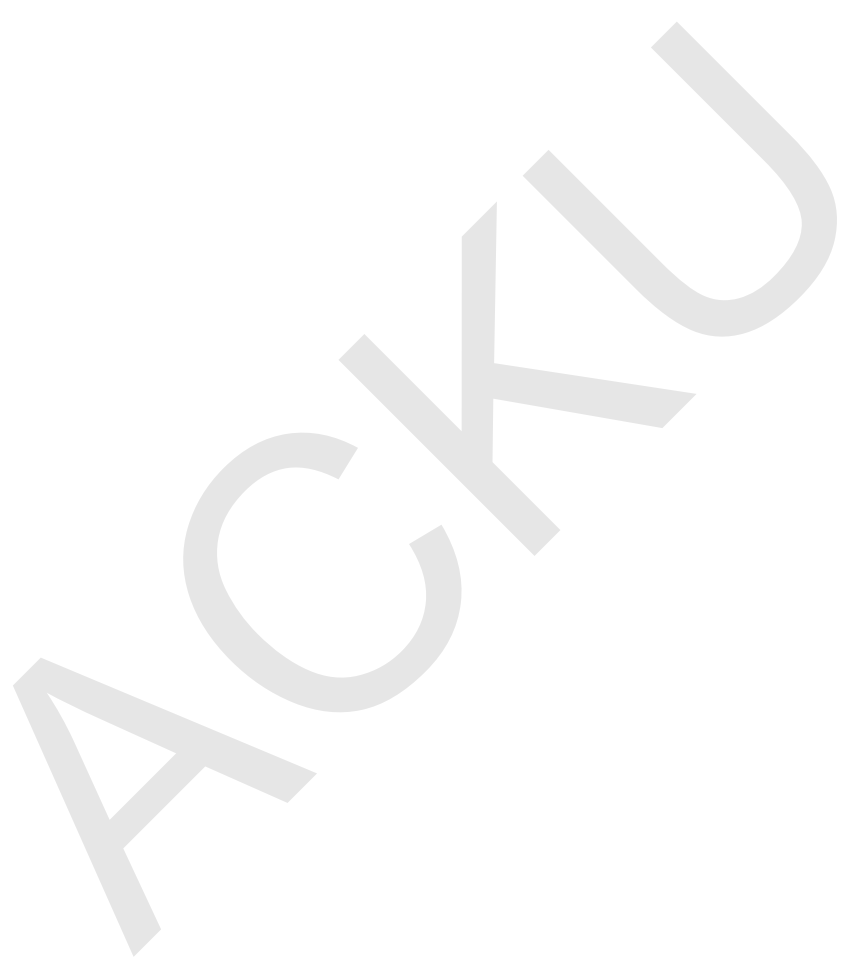




\section{Life}

I look at her one-day-old face,

and

she pouches her rose-petal lips,

and blinks-

merely for a second,

and goes back to sleep,

unaware of this world...

in clouds of white sheets.

A strange tenderness rushes

over, into my heart,

and I feel like crying...

I close my eyes.

Unconscious of thoughts,

thoughts find their way

to my lips,

and unaware of sound and silence,

a silent tear burns,

and disappears in a sigh,

"Ah...life, it has begun.

What will become of it?" 
The Invisibles

\section{"Listen... Ob watch...}

\section{You-People of the Earth, Watch!"}

I am here to stay in this world,

In this vast no man's world-not yours, not mine.

I saw the bombs devastate the land where I used to play.

I saw the ghastly choppers invade where I used to stay.

I cried when they stomped their dirty paws upon humanity, and when they crushed honor and honesty.

I walked on this world-not yours, not mine,

nor dead, nor alive — a sad silent twine,

letting the hurt bleed itself dry-no words, no sigh...

in this vast no man's world-not yours, not mine.

My tears burned in rage when they misused

the words Faith, Religion, God, and Nation,

their atrocities, their shameless perversions

reflecting-in innocent blood, in children's horrified gaze

hiding - in graves, in women's mute life - that horrible maze.

I cried when they insulted mothers and fathers,

and when crippled orphans wandered-in daze.

I wept bitterly when they robbed the dignity of my people, and when they stole the name of my people,

invisible in this world - not yours, not mine.

And then the Nightmare crept, suffocating, ugly, insanecovering the mouths of my people;

hiding the truth about my people;

speaking falsely about my people...my people?

And I screamed, "No, this is not the truth?"

I sobbed quietly when heroes died-unknown. 
They will not see the people free.

They will not smile again; walk again on a land—free. The nightmare continued spreading dastardly crimes in this amazing world-not yours, not mine.

Listen...O watch...You-people of the earth, watch! The war-worn human beings, stripped of dignity, running away in rags and dirt-from the assisted thieves towards the closed doors, behind which the world marches...

I did cry; I threw my small fists up in the sky, asking, "Why?" And the nightmare continues, creeping-decreed to destroy. But the people are here to stay in this worldin this vast no-man's world - not yours, not mine. And we will shout out the voiceless truth-about people, about innocent people in this world - not yours not mine. 


\section{Nightmare}

I dreamt having to leave

my birthplace,

disaster of war and persecution chasing me.

I dreamt landing on another land,

where people

wrote and spoke unlike me,

altered my name, without asking me

and labeled me, without knowing me

looking at my lifelong professional resume, concluding:

"Not approved! It does not have our seals!"

and,

"Must begin again!"

I dreamt that I was

sweating, in closed-off rooms

cleaning, in strangers' homes

shelving, in dusty storage rooms

sobbing, in glassed-up, muted cubes

Surviving,

breathing,

walking,

where the paths never ended...

and where logic was terminally ill.

I dreamt I cried alone,

thinking of a lost life,

watching my documents,

the results of lifelong work,

burning up... 
I woke up.

It was only a nightmare!

Or was it?

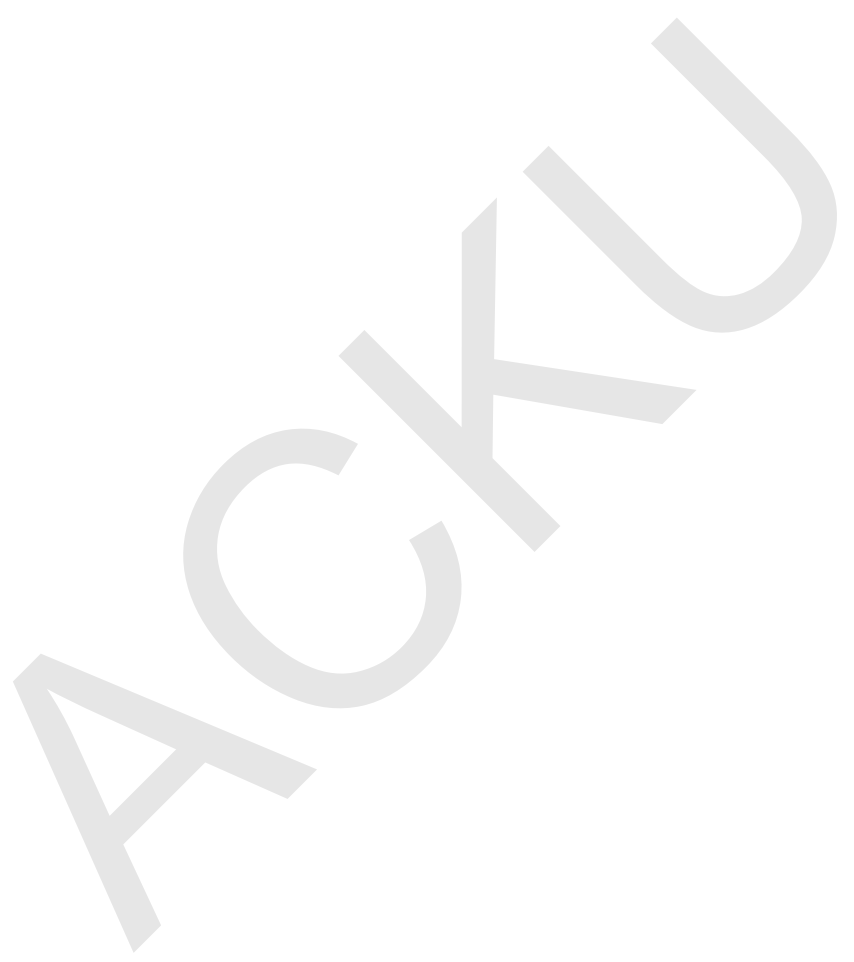




\section{No Illusions}

In the small room where

I used to ponder

over the young face,

smiling back in wonder,

inside the friendly mirror in my room,

from the magical world of mirrors;

a world colored in silence,

behind the thin sheet of a painted glass-

existing in nothingness...

Tempted I had been, in young eagerness, to reach in-

and touch

what was unreachable,

what was untouchable-

the unknown secrets of other worlds

in a young girl's room-in Kabul.

Leaning against the picture-spotted wall,

I had traveled thousands of miles...

Pictures I had cut from Post and Life

and Ariana, and Times, and

pictures I had walked into,

to look for the stories of lives

behind the mute images - in hide,

pictures that were small silent windows-

open to other worlds, all in a row,

on the walls of my room-in Kabul...

Where midnights used to find

my small figure, 
bending over old papers

or card-boards

making mute shapes come to life

with my pencils

or brush strokes,

while the smell of lilacs

in our yard

had saturated all my senses...

I had looked up

into a star-jeweled cobalt blue sky

above the guarding Asmaii mountain,

wondering...

what was it like-

the world's other side?

Where nights,

I would look up

at two blinking red lights,

far away...

Where universe was embracing me,

on the rooftop of our three-story house;

the cool breeze caressing my young face,

wrapping my slim body in a white cotton dress;

and the millions and millions of stars dancing

in the magnificent deep blue space...

And I would return to my small room, amazed,

where medical books, bed, and bones

occupied all the space,

at the corner of rooftop of our house;

Where I would sit to continue learning

names of hundreds of vessels and nerves - 
in the pages of Anatomy Gray, and skeletal bones in the wooden box, under my bed—in Kabul

Now, years later-

on the world's other side I sit back, patiently,

for a moment... at my desk

Looking at the young faces in a special school At Cherokee VillageWhere I teach hundreds of the mind's secrets, in a small classroom, where windows are shut. and I think, looking at the young facesfrom the world's other side, with no illusions, no wonders! 


\section{Once Broken}

She scribbled on the yellow page,

the color of seven falls on her face,

"The friendship is a puzzle;

I look for the pieces;

where did the friendship go?"

I remember,

those words, that small face,

those questioning brown eyes,

and my simple phrase:

"It is going to be okay!"

And a light kiss,

a warm embrace...

And now,

a silent sadness...

Sitting quietly in the kitchen,

breeze-like, yellow curtains

between me and

the tree-lined gray sky.

Looking at the bare oak trees,

far away traveling geese,

rain washed brown leaves

matted on the patio,

and the empty street

on a Thanksgiving day...

I scribble on my mind,

the color of many falls

on my face, 
"The friendships are puzzles;

I look for the pieces;

where did the friendship go?"

Silence breaths.

Occasional sizzling in the hot oven,

and the blowing sound

of the heat pump.

Not a small hug,

not even a light kiss.

It is not going to be okay!

Those deceptive patched cracks

are here to stay... 


\section{Overboard}

I turn around, to see-

or not to see?

their small faces,

their eyes,

in the silence of their cries;

or not to hear?

their soundless whispers...,

"How it would feel,

if I could talk?

How it would feel,

if I could walk?

How it would feel,

when it is warm?

How it feels,

when there is no fear

and no pain?

How it feels

when one is loved?"

Not knowing, not asking.

They are the children-

overboard;

no rescue boats,

no rescue rings,

in the rushing market of life.

Soundless, pleads my soul to me.

Breathless, I close my eyes-

not to see... 
not to hear...

in this dark winter night...

As we shudder-

my soul and me...

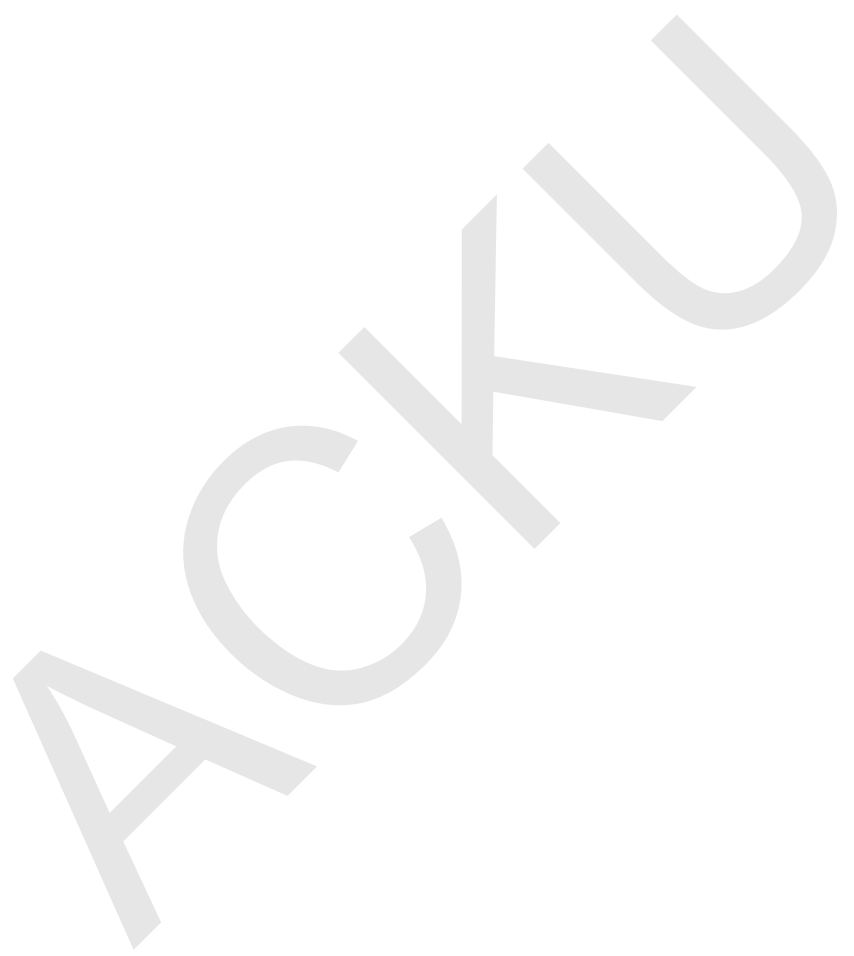




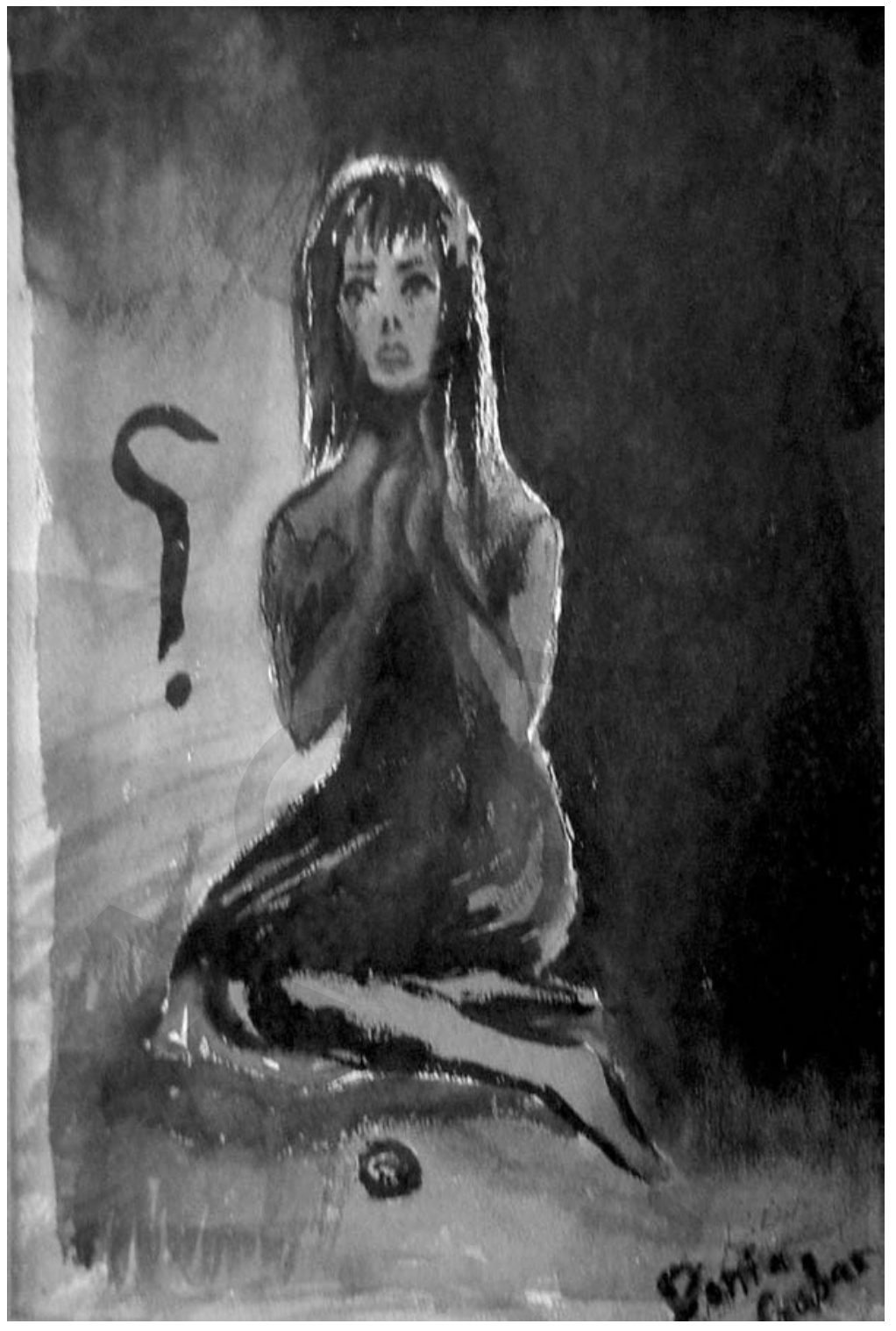

Overboard 


$$
\text { pe }
$$




\section{Remember?}

On the uneven sidewalks,

where the spring storm had left

unreachable tri-dimensional facts

in shallow layers of simple puddles.

And the aroma of jasmine flowers

made you dizzy,

looking...

down into the other deep blue sky,

lined by green coat oak guards,

standing

on the uneven stone sidewalks,

where your lace-tied braids

flew sideways,

while you,

jumped

over the many storm puddles,

pondering,

for just a moment, or more,

with the skip of a halfhearted beat,

looking

down

into the sky world of the puddles-

under your young quick feet,

jumping,

where you had picked armfuls of lilacs,

walking

on the uneven sidewalks. 


$$
\text { pe }
$$


Donia Gobar, MD, MPH

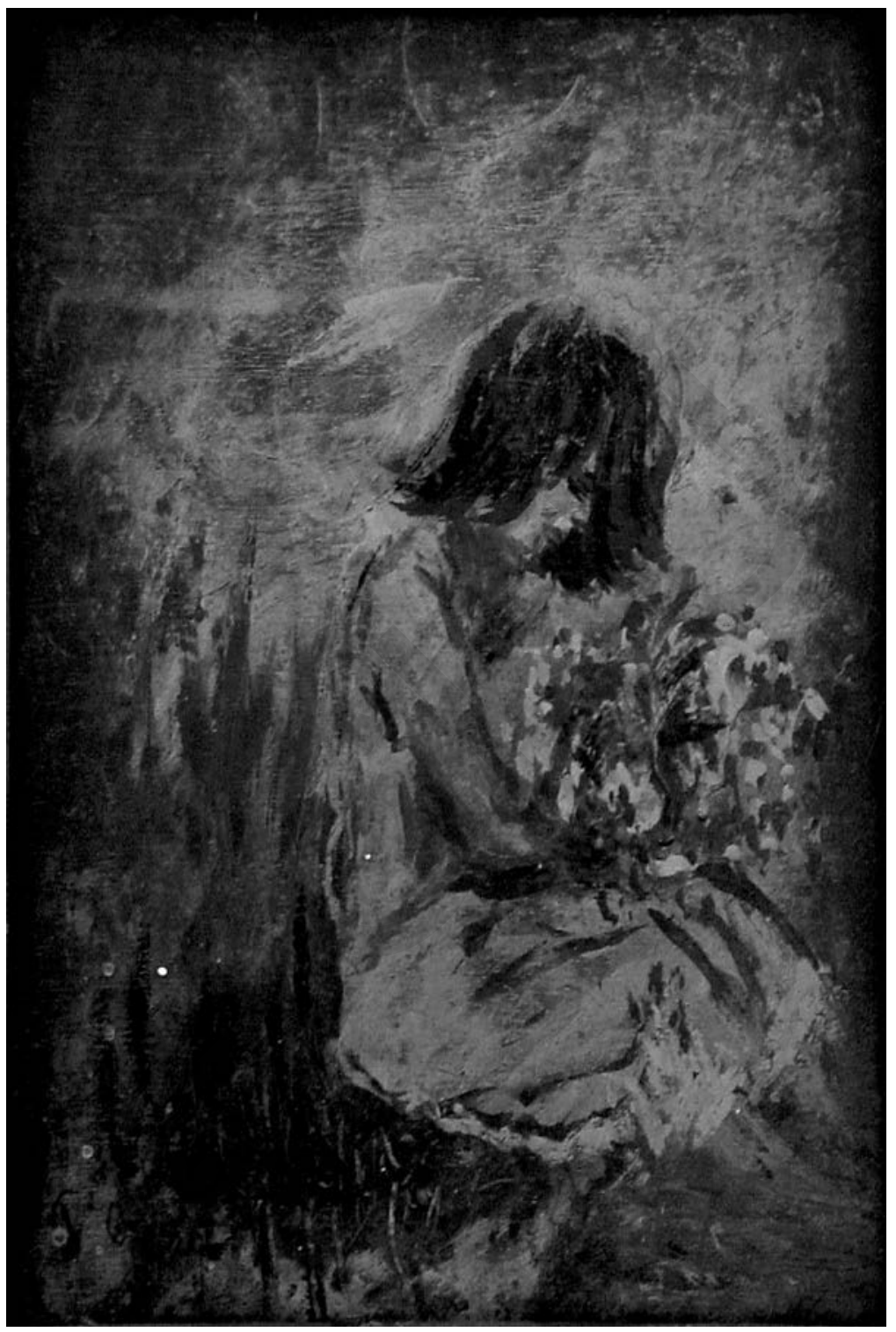

Remember 


$$
\text { pe }
$$




\section{Runaway}

"Think future," I say to myself, stepping over the present,

looking at the past,

pretending,

"No more hurting, no more remembering, only a faraway look..."

Shadow of a smile;

blinking away the tears;

not even a sigh...

The blurred vision of a ship — sinking.

A painful bruise throbbing in my chest.

"Turn to the present," I say to myself

It is cold.

It is dark.

I hold onto the warm memories,

still

lighting my way,

softly...

"Will you light

someone's way

someday?"

I whisper to myself,

"A runaway?" 


$$
\text { pe }
$$


Donia Gobar, MD, MPH

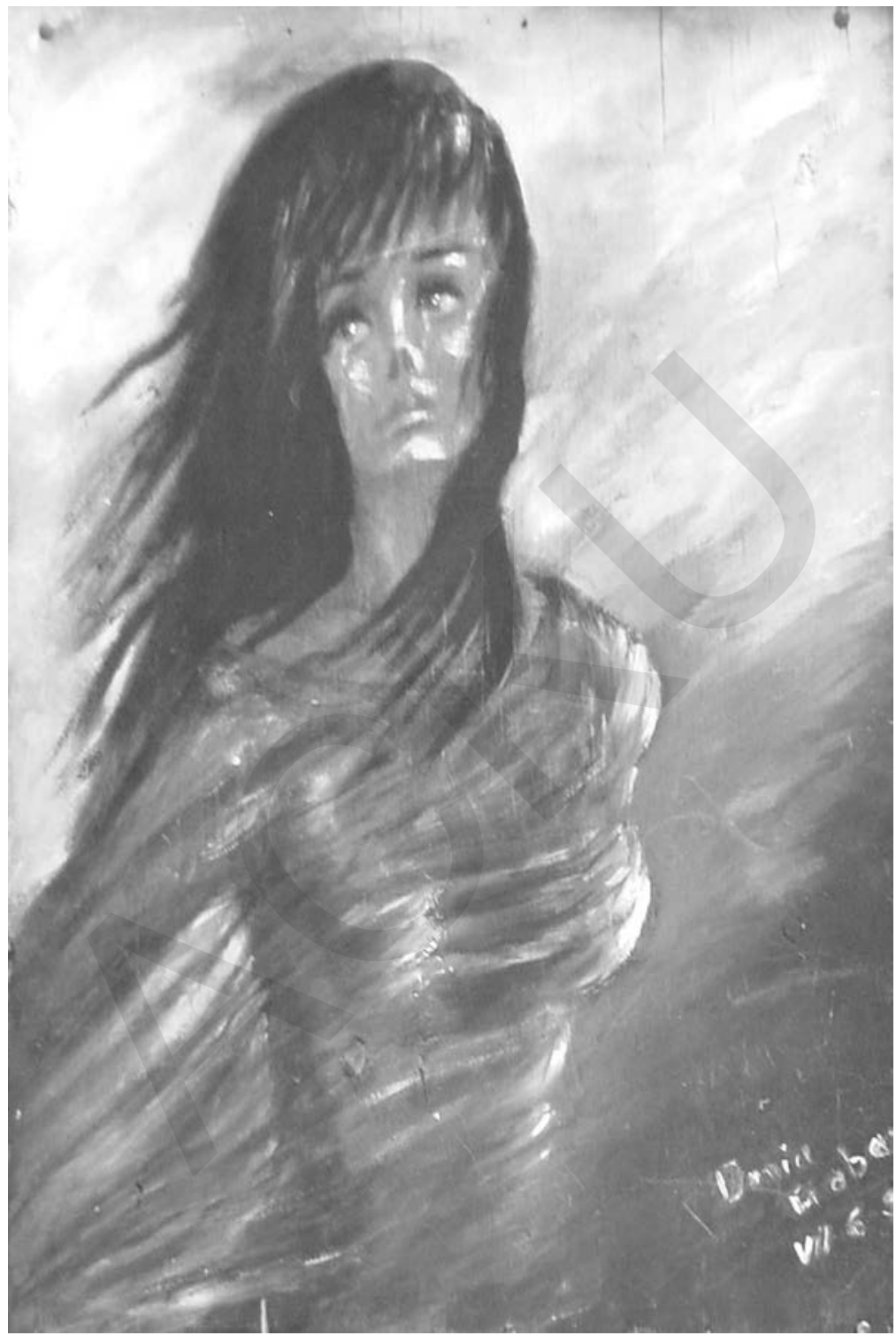

Runaway 


$$
\text { pe }
$$




\section{Stard Are Raining}

When in the poppy fields

of people's lives

cruel nights

were planting

the black flowers of sorrow;

and when

from dark eyes of the sky

sad stars were raining,

we were there...

When I saw

in silence of your eyes

the shaded river of human cries;

and when

on the thirsty meadow of a soul

your sad voice was raining,

we were there...

When

in the haven of night's deep forest,

in the path of brave knights,

diamonds of trust shimmered;

and when

with passing time

rain washed

the emeralds of the mind,

and

the periwinkle forget-me-nots, 
from the fields of memories

were rising

We were there...

\section{And when}

the crushing cascade of life,

over the rebellious heroes rushed,

and the image of freedom was carved,

We were there...

Now,

away from those fall-colored eyes,

in the flood-ridden valley of a heart

red flower of sorrow

is growing,

and from the dark skies

of thousand-tongue silent eyes

tear-washed stars are raining,

I am here. 


\section{Swingd}

The old car breathes the last,

and I walk away

on the searing, cracked driveway.

The looming branches

watch

the lonely front yard,

and the wrinkled arm of an old oak

is holding

a pair of swings -

hanging side by side.

The earth has settled into cracks,

where the coal miners' bony fingers

reach out

from the pit-land of the past

ripping the old green outdoor mask.

I look at the swings,

the forgotten doors to the past.

I had wrapped vines and roses

around the yellow ropes,

remembering the wind,

bare feet, and green slopes...

Pale and tired, she was,

sitting on her luggage

between the past

and

the future passage. 
My heart was pressed

inside some invisible fist.

Ah...laughter, laughter,

love and joy forever after...

Alas...time ran fast, leaving me

with the past;

and the swings are hiding

inside a sad, lonely dusk.

I enter a dark, empty corridor

And close behind me

the old green door. 
Donia Gobar, MD, MPH

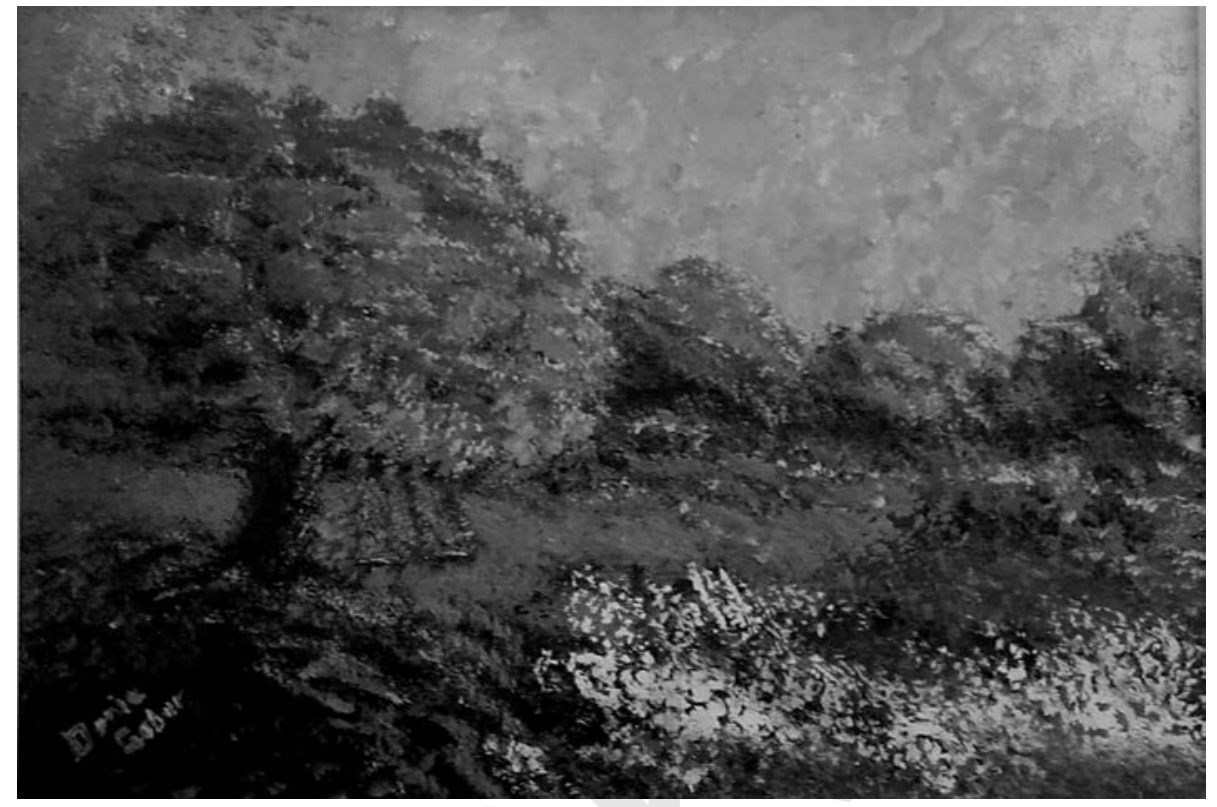

Swings

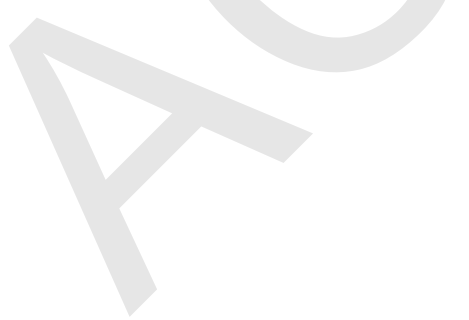




$$
\text { pe }
$$




\section{The Café}

Sounds of laughter and chatter

in the K. Pass Café in Parsons;

Kansas sky, hovering over

whispering secrets, fast cars,

and rushing walkers,

outside, in the small town.

Bob Dylan's voice scatters

verses,

as the words are blowing

in the wind,

as the ceiling fan stutters

inside...

As my pen stumbles

over

the paper napkins in haste,

"How was it then?"

Young age, all-night student café,

and Michigan snow-sleeping

outside...

"Future?" I had wondered then,

my bed waiting — untouched,

in the simple studio in Towers,

next to books and books...

A tired smile had softy rested

on my young face-then... 
That future is the past-now...

My past-a treasure...?

And tomorrow—no more a mystery.

My bed, old and soft, waiting

in a simple old house,

on a country road...

Books, handwritten sheets,

canvases, and color-soaked brushes...

And a calm smile... has rested

on my seasoned face-now. 


\section{The Beautiful World}

If only we all

were truly kind,

and knew empathy.

If only we all

did never lie,

and knew honesty.

If only we all

did not hurt others,

and knew sympathy.

If greed was used

to help,

and seek humanity.

If invention was for

keeping peace,

love, and equality.

If honor and dignity,

were people's

expected traits.

If we worked to live

and did not

live to work-for wealth.

If "the Earth"

meant

our Country. 


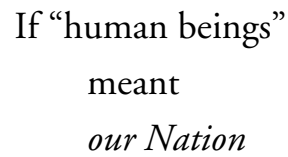

And if "the law of life"

meant

justice for humanity

Then...O then,

this would be a

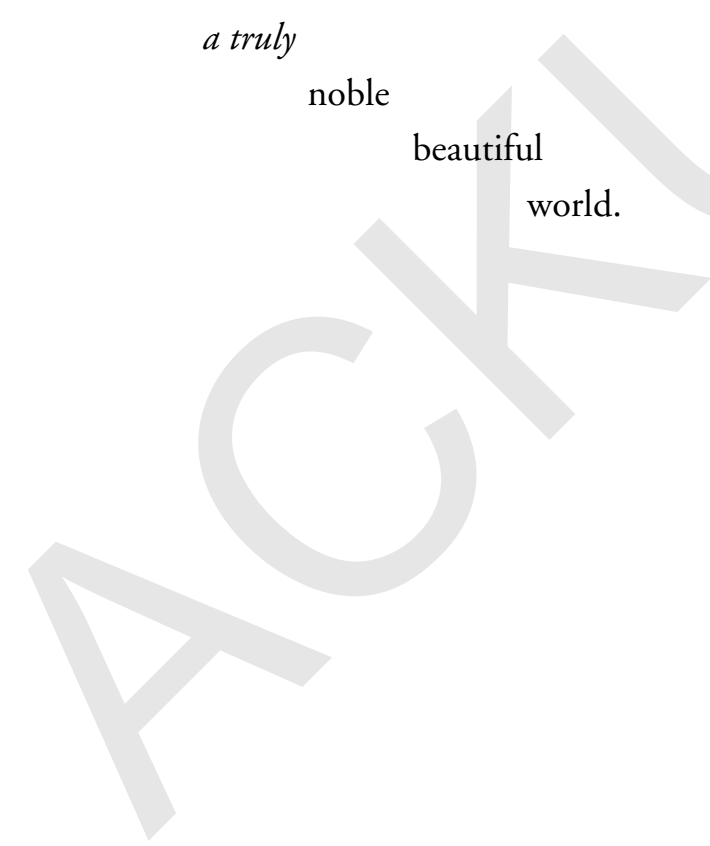




\section{The Closing Doord}

Look at those runaway eyes, shutters-from earth to skies.

Listen to that empty voice,

"How is the weather?"

feelings, getting lost, are running along the quiet, dark back roads.

She walks in the soft, secure corridors, in the everlasting land of her love, in her wondering mind, the place for those whom she loves...

Poor lashes struggle to keep

the warm, rushing flood in place.

She sees the closed door with a name on it, fading in the dust of timeunused, forsaken for too long...

"Good," she says through the lumps, through the overflowing flood, "it has not been needed..."

She fights back the tightness in her throat and the tagging sentiment in her mind. Defeated, broken lashes nail shut the forgotten door... 
Salty waters wash away the faded letters,

as she walks away,

farther and farther

from the door with no name on it.

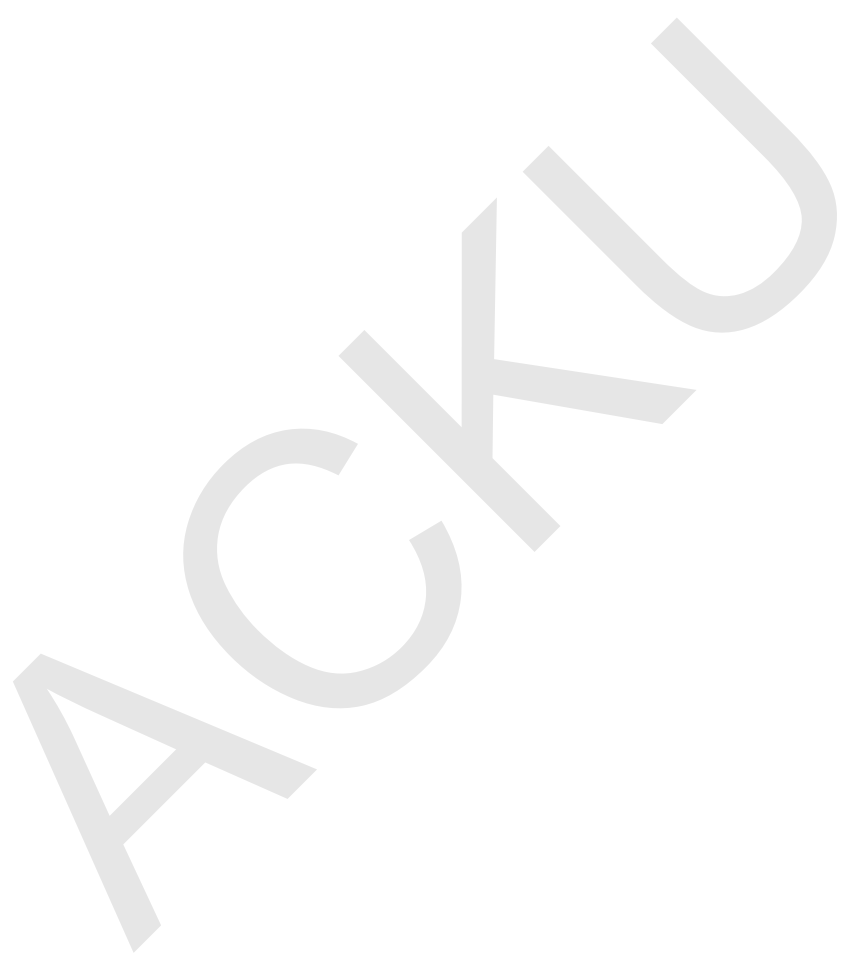




\section{The Last Season}

The old woman in the white hospital bed looked around the crowded room

in a nursing home, as an old sweeper, sweeping the fallen leaves off a neglected tomb. Her lost look, keeping guard, a mixture of gray and white worry in a vacuum of unknowingness, dipping in and out of the wells of sight. The pale cream wrinkled fingers weak and bony,

persistent, trudged along to get

the rectangular ivory object, with the call button on itthe lifeline for the bedridden patient, innocently leftjust a little out of reach for the exhausted hand to reach.

The old woman held her breath to cross the bridge

of pain in her back, thinking of a dry twigsnapresting against the white angular fence, when her children had jumped yesterday?

—Or last century?... 
Discerned with an automatic smile, the crisp-white-uniformed helper's face came close to the old timid face, while the efficient hands repositioned the pillows and the brace. This face was not that of her child, whose tears she had kissed away... moments before?

Or was it years before?

The cream-colored door fell in place, as the young nurse left the room, blocking the path of the sad, following gaze...

As the alphabet blocks she had made, had fallen in her children's room as the summer-blue door had closed behind the young mother leaving the room... moments ago?

—or was it years ago?

The old, lost look swept the empty space, a mixture of gray and white worry in a white, half-asleep resting home. 


\section{The Mute Shore In Me}

Look at those rushing, young emotions, racing with children of the sea, scattering diamonds of illusion.

Tipsy, with the wine of crimson dusk, rising, falling, and with half-breed twilights, crying, and with the mystic blue moon singing, dancing...

Again and again and again

The old shore in me watches

silently, stretching out its world-weary being, its vulnerable soft edges,

slowly

breaking,

sinking,

where the young waves play

night after night,

day after day... 


\section{The Portrait In Ink}

Outside,

in the stone-paved hallway

words and sentences-halfway

and children's step-getting away

and adults' pace

echo-my way.

Inside,

from the old school desk,

through the ink lines I make

on the legal pad's page

the questioning gaze

in the young boy's face

stares back in a daze.

Will he make it

-through the storms?

Will he survive

-through the norms?

In the world of foster homes

and juvenile courts.

Another lost young soul.

Another silent plea.

Another sad goodbye.

The portrait in ink,

now, folded in four-is gone,

with the yellow school bus,

and the pale-faced boy,

and the hand-waving at me... 


\section{The Teacher}

I am a simple person

Color blind

Gender blind

Religion blind

Borders blind

I am a learner

Always

Alert

Unafraid

Amazed

I am a follower

Of simple logic

Simple heroes

Tested wisdom

True freedom

I am a leader

Patient

Sincere

Fair

Aware

I am a healer

Color blind

Gender blind

Religion blind

Border blind 
The Invisibles

I am "Me"

Like everyone

Like no one...

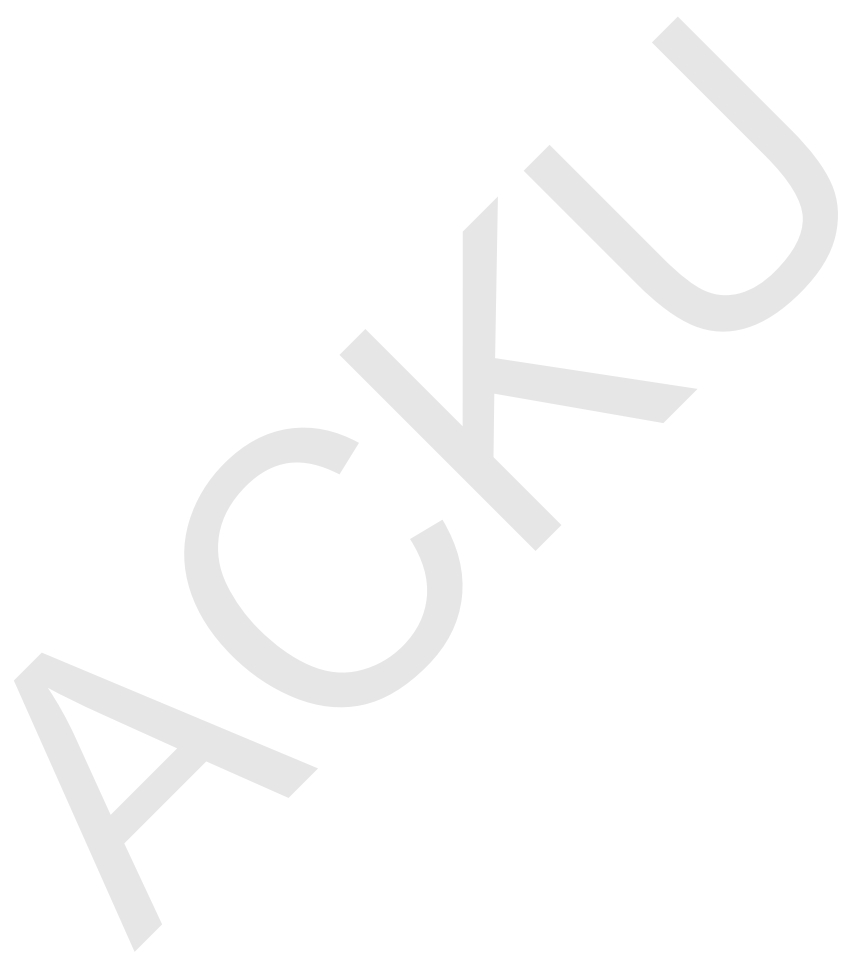




\section{The Ugly Face of Power}

They all shine,

sinking in soft velvet seats,

where ruby-colored drapes

mark the theater.

we all watch,

in the face of undeniable reality

the dissolving process of the "Nobodies"

whose lips

have not touched the tips

of golden skirts;

whose hands

have not polished spotted shoes

of "somebodies"-

in the murky halls of power.

We all sigh,

hearing the sound of imitated wisdom,

as twisted images fall into the mosaic

of popular subjects;

as hollow ideas bubble out

of a suffocated marshland,

where the bodies of truth and wisdom

have been slaughtered

and abandoned.

My thoughts-

the misplaced peaceful observers

struggle in dark,

as the lefts and rights lie in wait,

camouflaged, 
in the battlefield of contradictions,

to entrap

the scattered feverish emotions;

and,

as the distinct smell of rotted facts

marks the unmarked marshlands,

quietly, we house

the wounded images of the intellect

and of the innocent

in the concentration fields of survivors;

so that the great ugly powers may not ridicule

the hunchbacked carriers of freedom,

as we gasp for truth

at the edges of unmarked marshlands

in the battlefield of our lives. 


\section{They Can't Take Freedom From Me}

Do not pity me!

Think of me!

I won't let them take freedom from me.

Just a child I am, look at me!

Only a child, remember?

Superpower is passing through.

Remember!

The invader's shrewd and shameless,

calculated crimes

have made a masterpiece out of me.

Look at me!

My eyes used to sparkle with smiles.

My hands, while I still had them,

were soft and skilled.

I could run, my feet swift-like you.

I could jump and dance-like you.

I could see and laugh-like you.

Look at me!

It was a doll—a present from invaders.

Unlike Trojan horse,

this one had explosives

for children-like me.

Now,

I am not the child I used to be.

Go and tell the world,

"Remember!

Here are millions of masterpieces- 


\section{The Invisibles}

just like me;

the background-no more green,

no more alive,

is signed in blood-

Invaders"

Remember me, as my silent vow

echoes

in Afghanistan valleys,

"They can't take freedom from me."

"They can't take freedom from me." 


\section{Untouched}

Let me close my eyes

and forget

the hand of mankind-

changing

the giving earth,

the amazing earth,

into

a pierced,

battered,

stabbed

abstract.

Oh, let me remember,

to see,

for a moment,

and

to never

forget

the patient

marvelous

earth-

untouched. 
The Invisibles

\section{Voyager}

Ye' life, show me your cards;

empty hands do not scare me anymore.

And you - the winding roads ahead, your slippery twists and turns do not weary me anymore.

O darkness!

Show me the darkest of sights, and the creepiest of nights! My heart does not race in fear anymore.

And you, the cowardly powers of hypocrisy, your calculated and evil harmony, your fierce dark symphony, and the slippery, shapeless nature of your two-faced face do not deceive me anymore.

And ah, disaster, your unpredictable hit and run cruelty does not astonish me anymore; and your raving, blindfolded tyranny does not stop me anymore...

But oh, you-memories from the past, and hopes of tomorrow rain on me, softly, softly!

You are the only pleasures I would ask for, more and more... 
Donia Gobar, MD, MPH

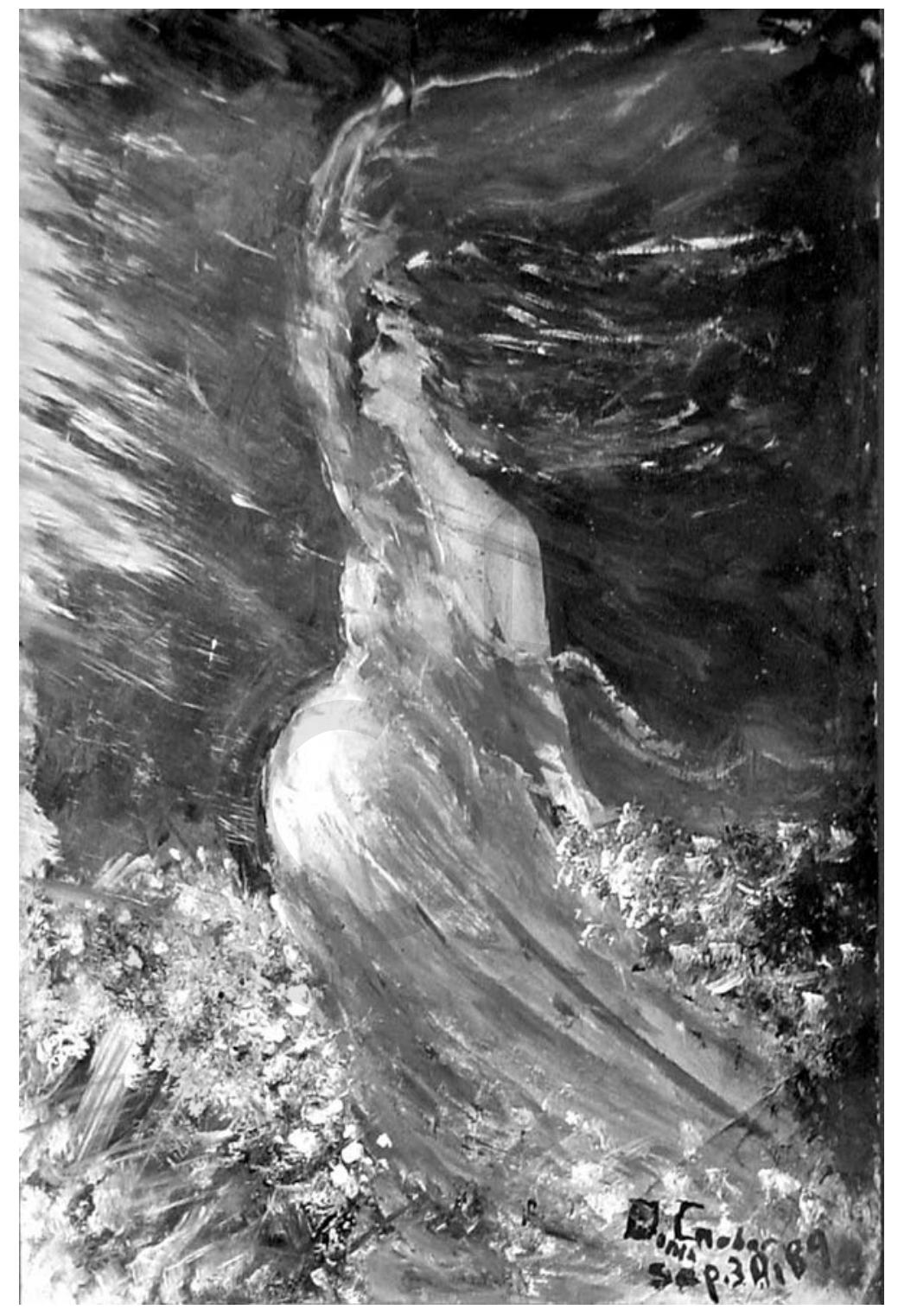

Voyager 


$$
\text { pe }
$$




\section{War}

Did you see?

Did you?

The lifeless limbs, the limbless lives, and the bloody curls around pain-struck faces...

Did you hear?

Did you?

The voiceless screams,

bewildered

in the pause of rushing time...

Did you shudder with rage?

Thinking of the cowards

watching the criminals

and their self-serving ideals...

Were you there?

Were you?

Watching the children's lives set

in chilling, bloody twilights of war

Alas, alas...

All those unspoken words...

Tell me, did you weep?

Did you ask?

"Why...

why?" 


$$
\text { pe }
$$


Donia Gobar, $M D, M P H$

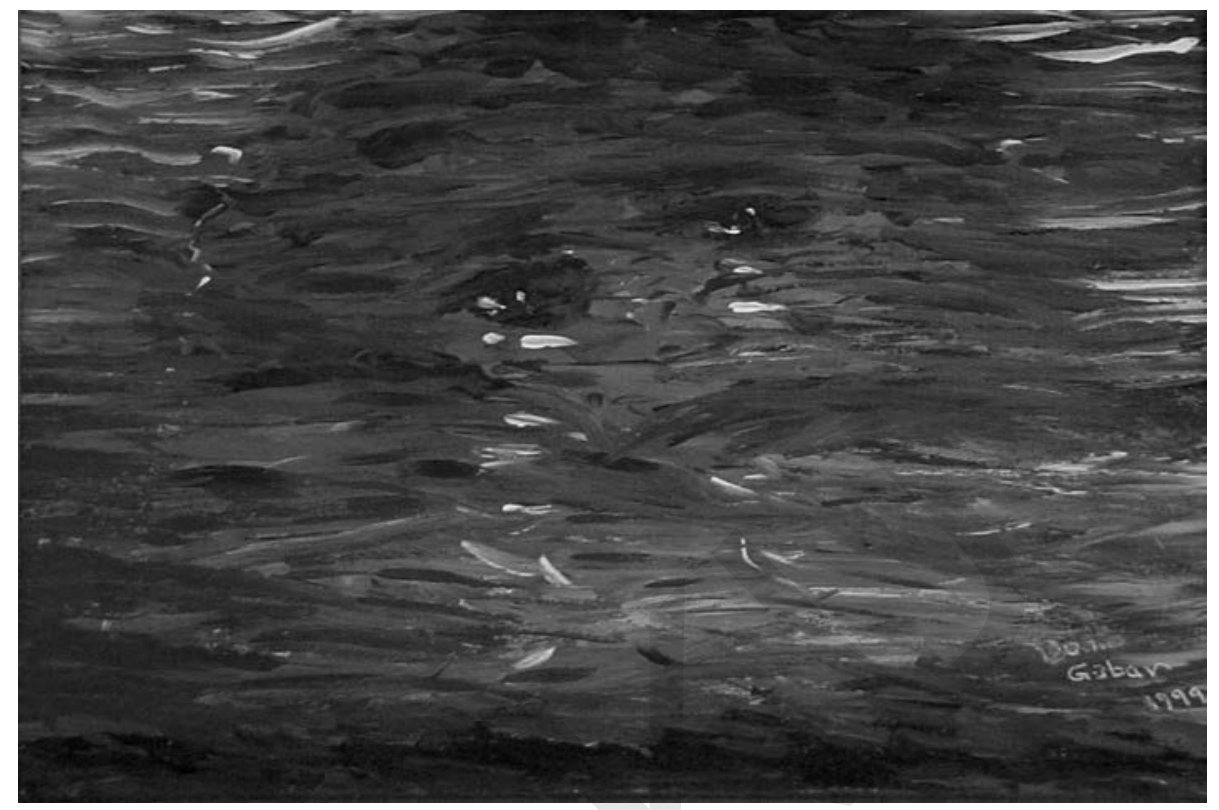

War 


$$
\text { pe }
$$




\section{What Am I?}

The long wooden table,

and

the mustard-colored old school-

somewhere in east coast land...

The weightless popcorn—scattered, pale, forlorn,

waiting

to be picked

by all those fingers-

old and robust, or carefully manicured;

to disappear

beyond dried-up plums or soft cherries

of all those mouths

—one by one.

Hearing their easy flow of words-

a language not mine,

I walk away in my mind,

getting lost in strangers' shores...

Ah, rushing, crushing waves...

what am I?

Awake and alone in grave-

this airless tiny ditch

pressed down by life-

this blind weight.

A soundless scream

in long, dead-end roads. 
Silently waiting, waiting

Watching, watching-

the senseless craze...

A painful wound - a flameless burn

A searching wave at invisible shores...

What am I?

My body—a stretcher for lives

My mind-a runaway soul

in nightmare corridors...

A rebellious slave-

chased in hateful dark halls?

Running, gasping-between closing walls.

Small-talk messengers holding

my eyelids open;

mute tears pounding at the pretence walls

"Yes," "No," and "Thanks," I say...

What am I?

Footsteps, once so small-

skipping, running, dancing

on the dust, on the mud,

on the asphalt roads

slowing down-

hushed in deep thoughts,

faraway-in college compasses,

on rented floors,

on hospital grounds, in my patients' rooms.

In sidewalk cafes,

in strangers' homes, 
in old, musty classrooms

pacing...

What am I?

"Look down!

The mountains are getting lost;

tears leave; I will return at last."

I had watched then

I had said then

"Look! I can exist in them all_-

the world around

the world inside,

the world away_miles and miles..."

I smile now,

a shrewd little smile...

Listen!

I can hush the cry's echo

in hollow nights...

See?

I look at the young green leaves,

and

touch so tenderly the yellow buttercups,

and dewdrops at dawn...

Yet,

raindrops in gray twilights

sadly pause,

and run on my soul,

and

I smile, 
a shrewd little smile,

while it hurts, while it burns...

what am I?

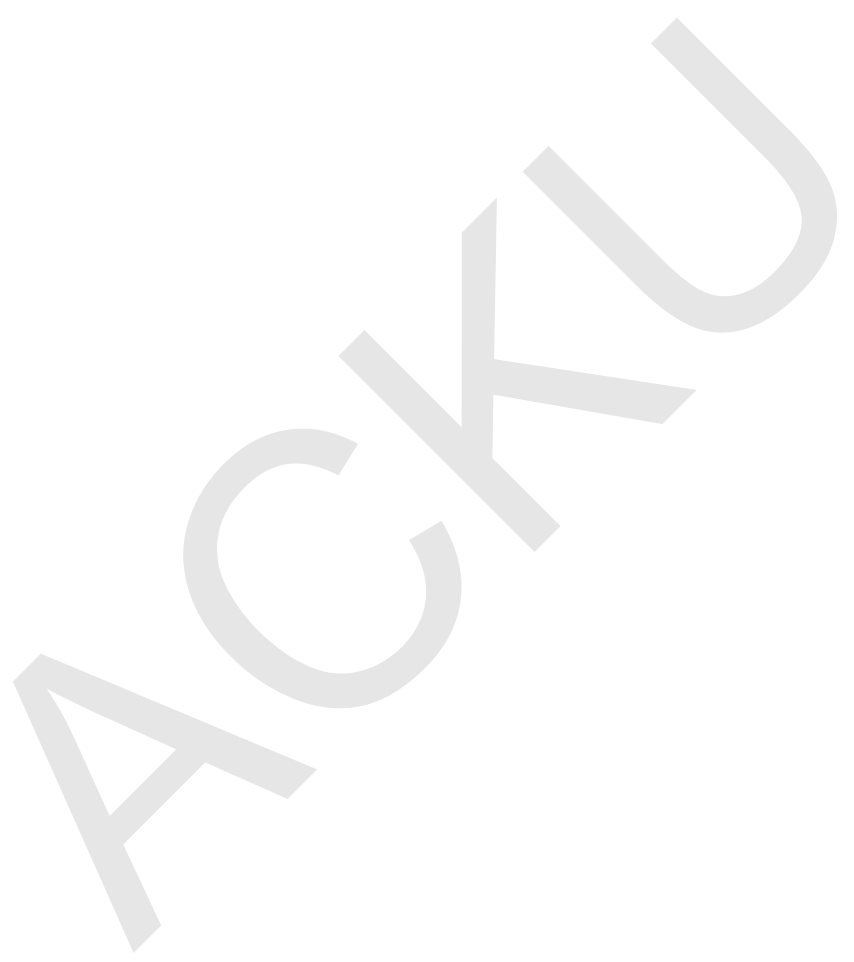


Donia Gobar, MD, MPH

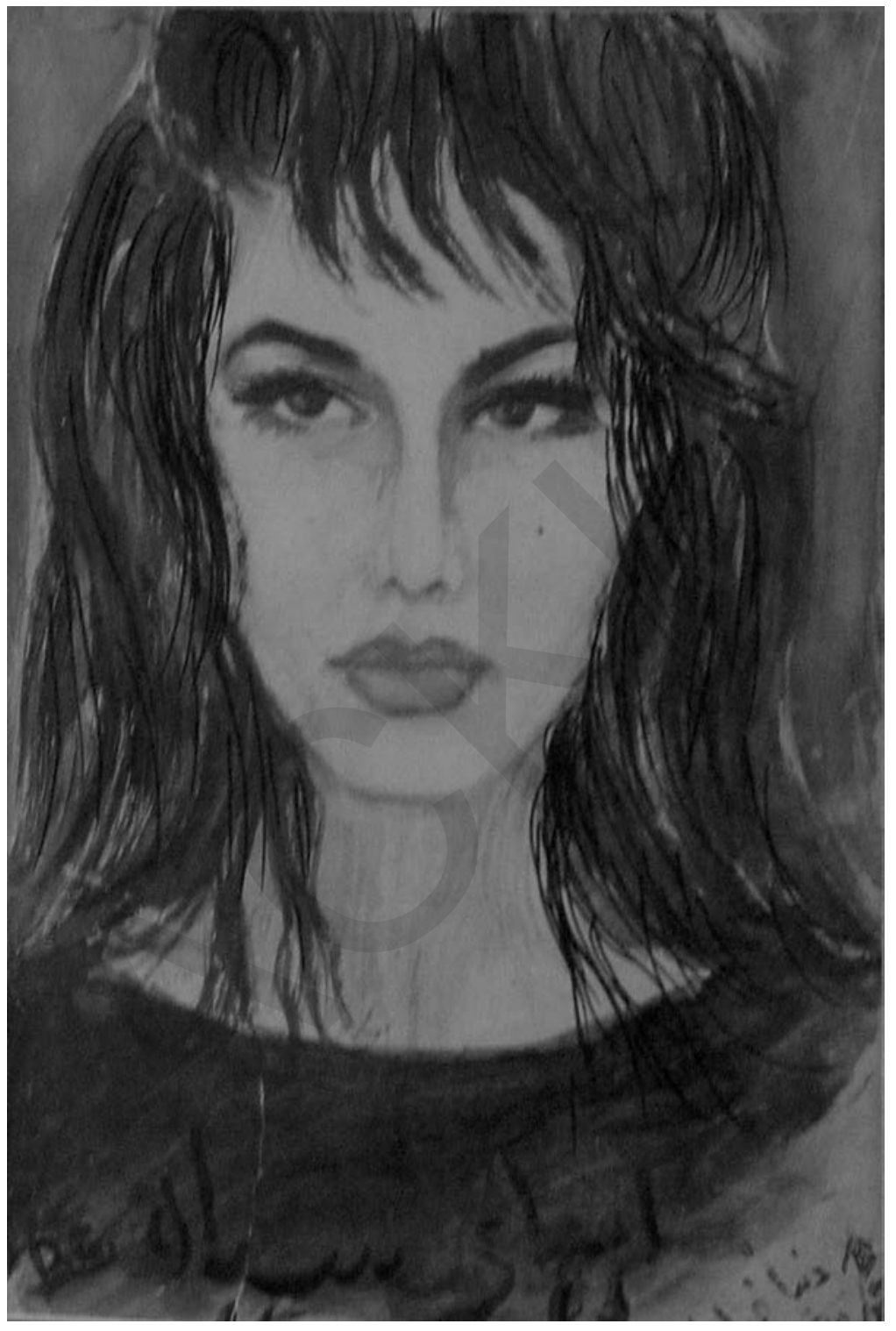

What Am I? 


$$
\text { pe }
$$




\section{Wisbing...}

Oh little, soft, magical snowflakes...

look at those shiny brown boots.

Look at the soft, furry white lining...

only one pair, just the size of my boots.

God, they must be real warm...

oh, how I could run-

on the muddy back alee,

and on the crisp icy snow,

in those brown, lovely, warm boots.

Oh, my nose, it is numb...

and freezing.

My pinky finger and my thumb

frozen in place...

and surely I don't feel my toes.

Well,

maybe tonight I will dream...

being warm

in those shiny rubber boots,

having in my arms

that doll

with the bonnet and the white boots. 


$$
\text { pe }
$$


Donia Gobar, $M D, M P H$

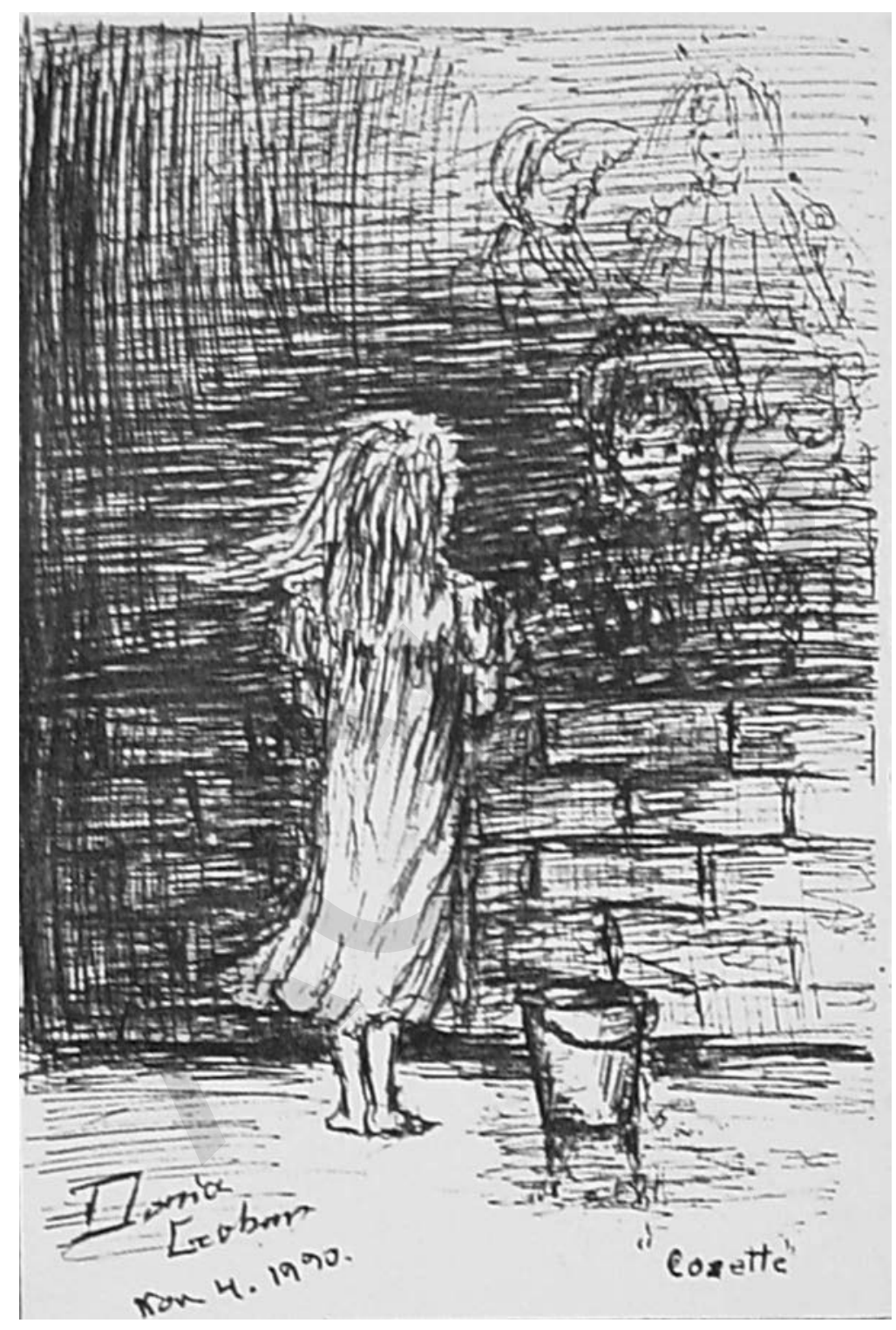

Wishing 


$$
\text { pe }
$$




\section{About the Author}

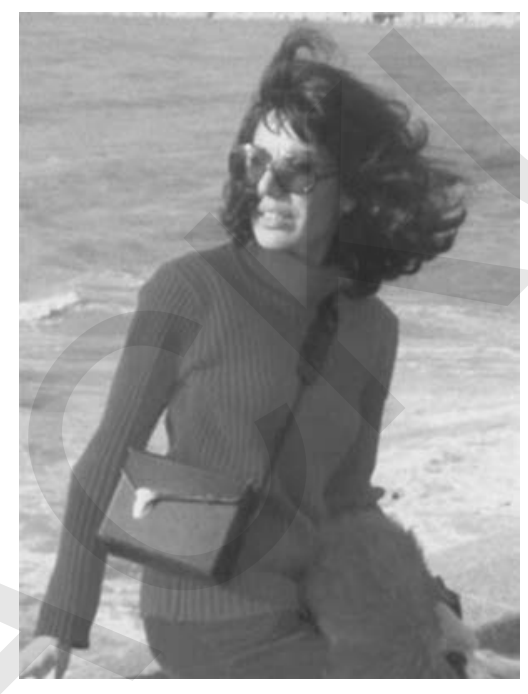

Donia Gobar is the daughter of Salia Ghobar and M.G.M. Ghobar, the author of "Afghanistan in the Course of History." Born in Kabul, Afghanistan, she graduated from Kabul University, School of Medicine, specializing in Obstetrics and Gynecology. She continued her medical career in West Berlin, with a specialty in Internal Medicine. Dr. Gobar was awarded a Masters degree in Public Health from the University of Michigan, and conducted biomedical research at the University of Illinois. In addition, Dr. Gobar undertook the National Teachers Examination and went on to earn alternative teaching certificates for both Massachusetts and Kansas. Currently, she is an instructor and the creative force behind a curriculum called "Concept of Health." Her daughter is attending medical school in the US. Dr. Gobar's hobbies include painting, creative writing, and sculpting. 
Dr. Gobar is the founder of the True Humanity Club (http:// clubs.yahoo.com/clubs/Truehumanity). She is a member of National Education Association, KNEA-Human \& Civil Rights Commission. She has also done several art exhibitions in places such as George Mason University (Society of Afghan Artists, 1999), Pittsburg Arts Council (1999, 2000, 2001, and 2003), and Fort Scott, Kansas (2000). While a medical student, when making a sculpture, her picture was selected to appear on the cover of Overseas magazine, as well as in Scala magazine. Some of her work can be viewed at www.geocities.com/ dgobard/Donia.htm.

Dr. Gobar is listed as a literary writer in "The Encyclopedia of Persian Literature In Afghanistan." Her work includes "Aya," which was published in the "Top Ten Short Stories of 1994" (American Literary Press, Inc.), Dunya-e-Jawanan, and Afghan Magazine (Lemar-Aftaab). Other short stories of hers, written and published in Persian (Dari) language, have appeared in various magazines and newspapers in Kabul, Germany and Canada. She was awarded the International Poet of Merit Award in 2000-2001 and 2003. She has also received the Editor's Choice Award, and her work has been chosen for Poetry's Elite-Best Poets of Year 2000 by the International Society of Poets (ISP). Her poems have been featured on ISP's "Sound of Poetry" CDs. 
0-595-29303-4 


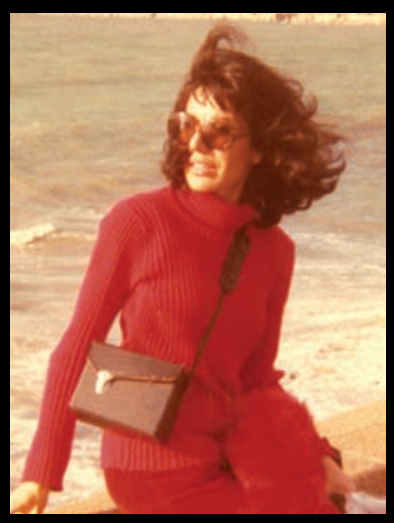

About the Author

Donia Gobar, MD, MPH, born and raised in Afghanistan, immigrated to Germany and then America following the USSR's invasion of Afghanistan. Her published works include poems and short stories. Her awards through International Society of Poets include the Merit, Editor \& Sound of Poetry. She's had art exhibitions in Virginia and Kansas.

ISBN: 0-595-75026-5

iUniverse, Inc.

2021 Pine Lake Rd.

Suite 100

Lincoln, NE 68512

www.iuniverse.com

Credit for graphic: Donia Gobar
The Invisibles is a unique collection of poetry and artwork, a creation in which the style of written work and the brush-stroked images take the reader into an amazing and brave world, where the magical dawns and the exotic twilights of the East and West intertwine; where days and nights seek each other in the fantastic voyage of life.

Each poem is a previously untold story from the world of the invisible, whose voices we may not hear and whose faces we may not see; whose pain we may not feel and whose languages we may not understand; and whose heroism we may not notice. These are the innocent and noble human beings that are pressured by social injustice, caught in the crossfire of mindless and violent powers.

This book includes 19 prints of original paintings. These paintings reflect some of the artist's thoughts and perceptions throughout a stormy life across the continents.

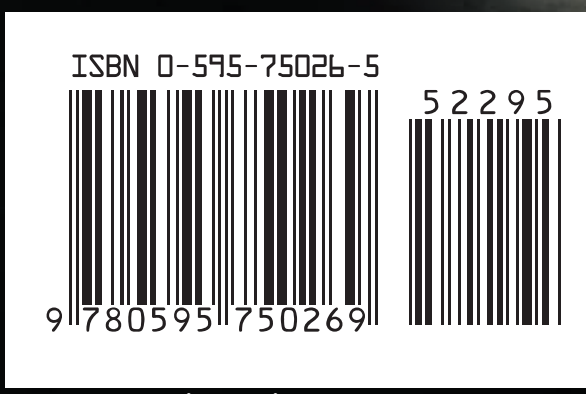

w w w. i u n iverse.com
$\$ 22.95$ U.S: $\$ 30.95$ Canad $£ 19.99$ U.K

iUniverse"
D. $G$. 